\title{
Geologic Map of the Northeast Flank of Mauna Loa Volcano, Island of Hawai'i, Hawaii
}

By Frank A. Trusdell and John P. Lockwood

Pamphlet to accompany

Scientific Investigations Map 2932-A

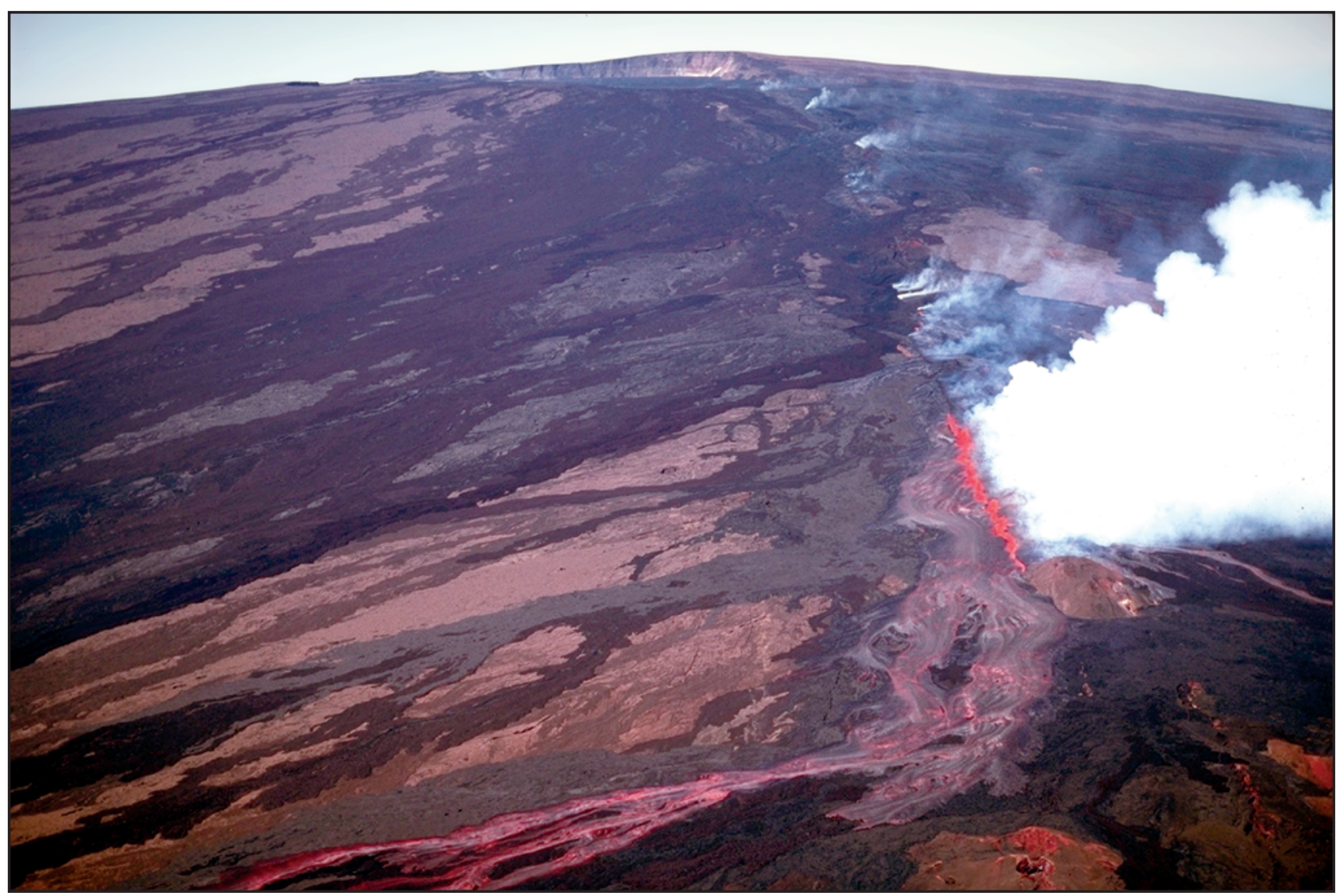

Aerial view towards the southwest of the 1984 eruption from the Northeast Rift Zone of Mauna Loa volcano, Island of Hawai í, Hawaii. Photograph by Robert W. Decker, U.S. Geological Survey.

2017

U.S. Department of the Interior

U.S. Geological Survey 



\section{Contents}

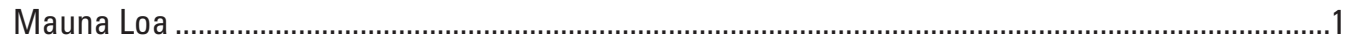

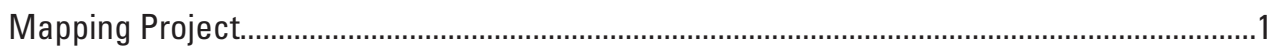

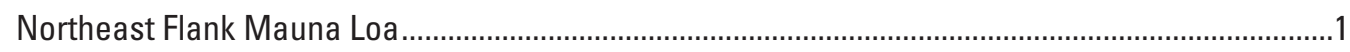

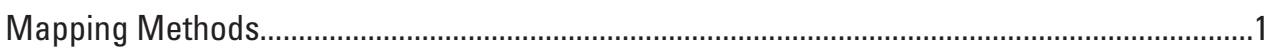

Digital Database

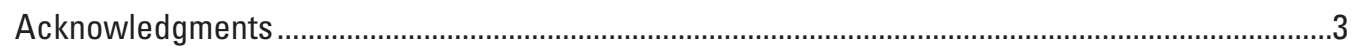

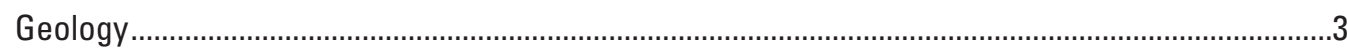

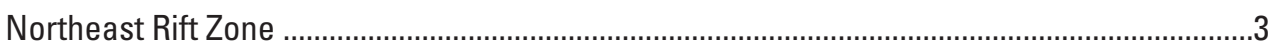

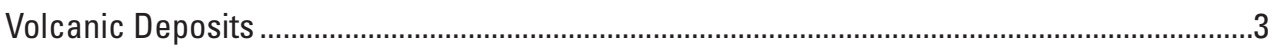

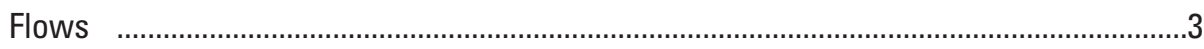

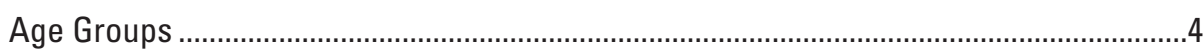

Age Group 0 (Historical period: A.D. 1843 and younger) ............................................

Age Group 1 (pre-A.D. 1843-1,000 yr B.P.) ……………......................................

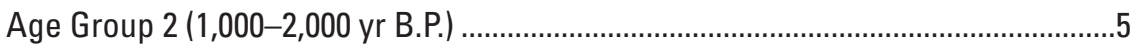

Age Group $3(2,000-3,000$ yr B.P.) ….............................................................

Age Group $4(3,000-4,000$ yr B.P.) ....................................................................

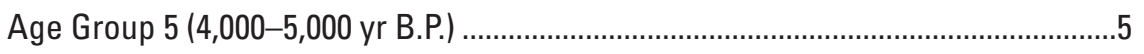

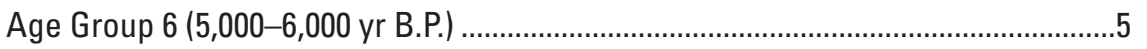

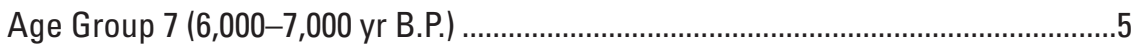

Age Group 8 (7,000-8,000 yr B.P.) .................................................................

Age Group 9 (8,000-9,000 yr B.P.) ...............................................................

Age Group 10 (9,000-10,000 yr B.P.) ……….................................................

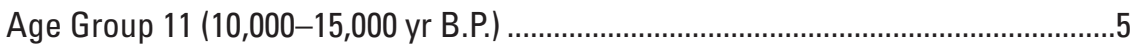

Age Group 12 (15,000-20,000 yr B.P.) ...........................................................

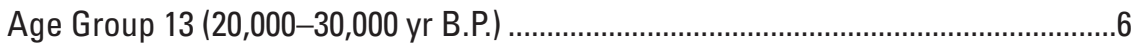

Age Group 14 (30,000-100,000 yr B.P.) ………………......................................

Age Group 15 (>100,000 yr B.P.) ….................................................................

Surficial Sedimentary Deposits ........................................................................................

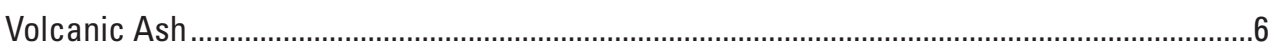

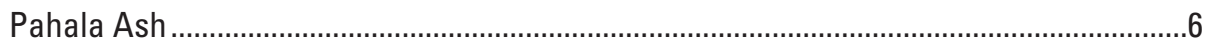

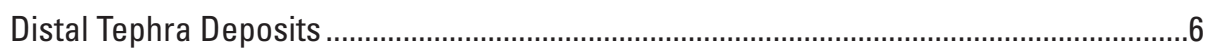

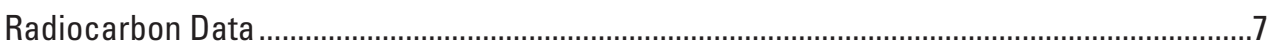

Description of Map Units.......................................................................................................

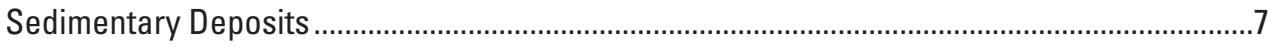

Surficial Deposits (Holocene) ........................................................................................

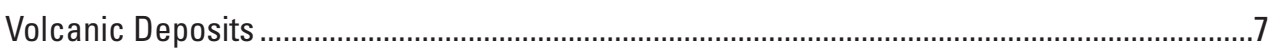

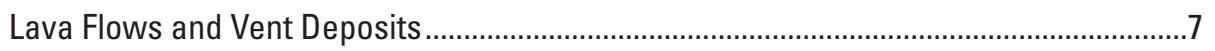

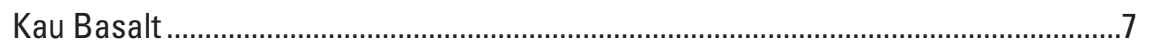

Age Group 0 (A.D. 1843 and younger; Holocene) …………….............................

Age Group 1 (pre-A.D. 1843-1,000 yr B.P.; Holocene) ..........................................

Age Group 2 (1,000-2,000 yr B.P.; Holocene) ................................................

Age Group 3 (2,000-3,000 yr B.P.; Holocene) ...............................................10

Age Group 4 (3,000-4,000 yr B.P.; Holocene) ...................................................11

Age Group 5 (4,000-5,000 yr B.P.; Holocene) ................................................12

Age Group 6 (5,000-6,000 yr B.P.; Holocene) ................................................12

Age Group 7 (6,000-7,000 yr B.P.; Holocene) ...............................................13

Age Group 8 (7,000-8,000 yr B.P.; Holocene) ................................................13 
Age Group 9 (8,000-9,000 yr B.P.; Holocene) ...................................................14

Age Group 10 (9,000-10,000 yr B.P.; Holocene) ................................................15

Age Group 11 (10,000-15,000 yr B.P.; Holocene and Pleistocene) ....................15

Age Group 12 (15,000-20,000 yr B.P.; Pleistocene) ............................................16

Age Group 13 (20,000-30,000 yr B.P.; Pleistocene) ..........................................16

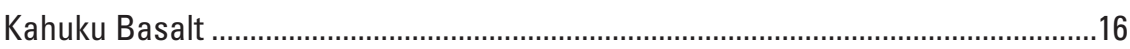

Age Group 14 (30,000-100,000 yr B.P.; Pleistocene) ........................................16

Ninole Basalt ..................................................................................................... 16

Age Group 15 (>100,000 yr B.P.; Pleistocene) ................................................16

Distal Tephra Deposits ............................................................................................16

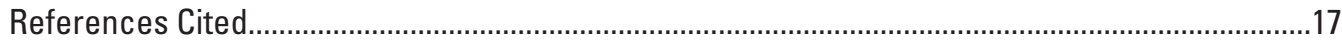

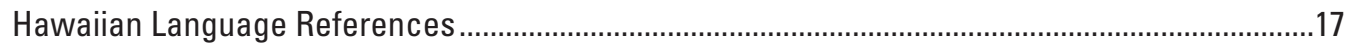

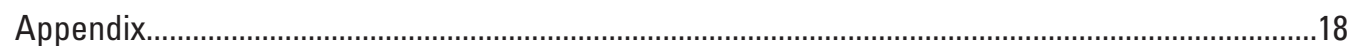

\section{Figures}

1. Map showing subaerial volcanoes forming Island of Hawai'i, fissures on Mauna Loa, quadrangle boundaries, and study area.

\section{Tables}

1. Summary statistics of historical (after A.D. 1843) eruptions on Mauna Loa's northeast flank, Island of Hawai'i, Hawaii. .......................................................................................

2. Radiocarbon ages of samples from the northeast flank of Mauna Loa volcano, Island of

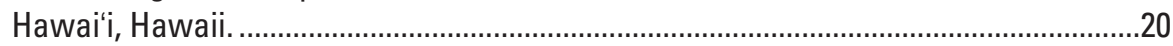

3. Explanation of map unit labels for Mauna Loa, Island of Hawai'i, Hawaii...................sheet 1 


\section{Mauna Loa}

Mauna Loa, the largest volcano on Earth, has erupted 33 times since written descriptions became available starting in A.D. 1843. Some eruptions begin with only brief seismic unrest, although others follow several months to a year of increased seismicity. Once underway, an eruption sheds lava flows that may reach the sea in less than $24 \mathrm{hr}$, severing roads and utilities. For example, the 1950 flows from the Southwest Rift Zone eruption advanced at an average rate of $9.6 \mathrm{~km} / \mathrm{hr}$ (Finch and Macdonald, 1953), although the flows must have traveled much faster near the eruptive vents. The flows reached the ocean in approximately $3 \mathrm{hr}$ from the beginning of the eruption (Finch and Macdonald, 1953). In terms of eruption frequency, preeruption warning, and rapid flow emplacement, Mauna Loa has great volcanic-hazard potential for the Island of Hawai' $i$. Volcanic hazards on Mauna Loa may be anticipated, and risk substantially mitigated, by documenting the past activity to refine our knowledge of the hazards and by alerting the public and local government officials to our findings and their implication for hazards assessments and risk.

\section{Mapping Project}

The Mauna Loa mapping project will generate detailed geologic maps and associated digital databases of Mauna Loa (fig. 1) on the Island of Hawai 'i, Hawaii. This temporal and spatial record of Mauna Loa's eruptive activity for the last $10,000 \mathrm{yr}$ provides a geologic framework to evaluate eruptive processes at large basaltic shield volcanoes and to determine the long-term frequency and style of Mauna Loa eruptions as guides for volcanic-hazards appraisals and land-use decisions (Trusdell, 1995).

The subaerial volcanic geology of Mauna Loa (fig. 1) is being mapped and digitally compiled on five maps at 1:50,000 scale to show the extent of surface flows. Approximately 500 flows have been identified and their attributes compiled in a large database. This temporal and spatial record of eruptive activity for the last 30,000 years provides a geologic framework to interpret the long-term frequency and style of Mauna Loa eruptions. These data permit quantitative analysis of the distribution of eruptive products through time and improve evaluation of volcanic risk and land-use decisions (Trusdell, 1995).

\section{Northeast Flank Mauna Loa}

The map of the northeast flank of Mauna Loa shows the distribution and relations of volcanic and surficial sedimentary deposits. It incorporates previously reported work published in generalized small-scale maps (Lockwood and Lipman, 1987; Buchanan-Banks, 1993; Lockwood, 1995; Wolfe and Morris, 1996). The simplified unit labels on the map are non-unique labels that provide quick access to the unit morphology, age, mineralogy, and stratigraphy. This non-unique unit label may be used for an entirely different unit on a different flank of Mauna Loa.

\section{Mapping Methods}

The geology was mapped using vertical aerial photos taken in 1977 and 1978. Extensive field work required walking the contacts to distinguish individual flow units and intraflow boundaries, including morphologic contacts between ' $a$ 'ā and pāhoehoe. Where the terrain and jungle obscured contacts, we created a grid pattern of transects; the ensuing contacts were extrapolated between transects from geological and botanical inferences. Details from aerial photos were transferred to 1:24,000-scale base-stable material (greenlines) via a photogrammetric stereoplotter (Kern model PG-2). After details were finalized, greenlines were scanned and brought into ArcInfo to create the database.

Reliably correlating discontinuous exposures from outcrop to outcrop and through heavily vegetated areas is a major challenge in mapping a volcano that consists entirely of compositionally similar tholeiitic basalt. Criteria used for correlation include phenocryst size, morphology, and proportion; groundmass texture; vesicle shape; vesicle linings (magnesioferrite); surface flow morphology; paleomagnetic pole directions; rock chemistry; and varied evidence on relative and absolute ages. Paleomagnetic poles are an indispensable tool for making correlations between flows over large distances and, especially, through dense jungle. Individual flows typically change from pāhoehoe near the vent to 'a'ā downslope, especially for highdischarge eruptions; low-discharge eruptions may result in the distal emplacement of pāhoehoe through efficient lava-tube delivery systems.

The pre-1843 lava flows and tephra deposits are divided into 15 age groups by several methods. About half the flows were dated directly (92 radiocarbon ages), using carbonized organic material recovered from beneath each flow (Lockwood and Lipman, 1980). For undated flows, relative ages are assigned on the basis of flow and mineral weathering, surface color, amount of soil and ash accumulation, degree and type of vegetative cover, and stratigraphic relations with adjoining dated flows.

We use surface color effectively as an indirect indicator of age. Young flows are initially black. As the rock is exposed to direct sunlight, the color changes from black to dull black, progressing to grays, browns, tans, orange, and, finally, reds hues. The longer the rock is exposed to direct sunlight, the greater the color progression. Lipman (1980) used this color scheme effectively to tentatively classify the ages of eruptive units. In addition, soil and ash accumulation are used as an indirect indicator of age. The thickness of ash, however, may also be a function of proximity to the contributing source(s).

\section{Digital Database}

The digital database contains all the information shown in the printed publication at 1:50,000 scale, but it is accurate to $1: 24,000$ scale. It is structured on a unique three-digit flow identification number (FID; for example, FID 831), which is assigned to each flow unit mapped on Mauna Loa. The FID is essential as a unique descriptor for unit identification in the database; it is included at the end of each unit description in 


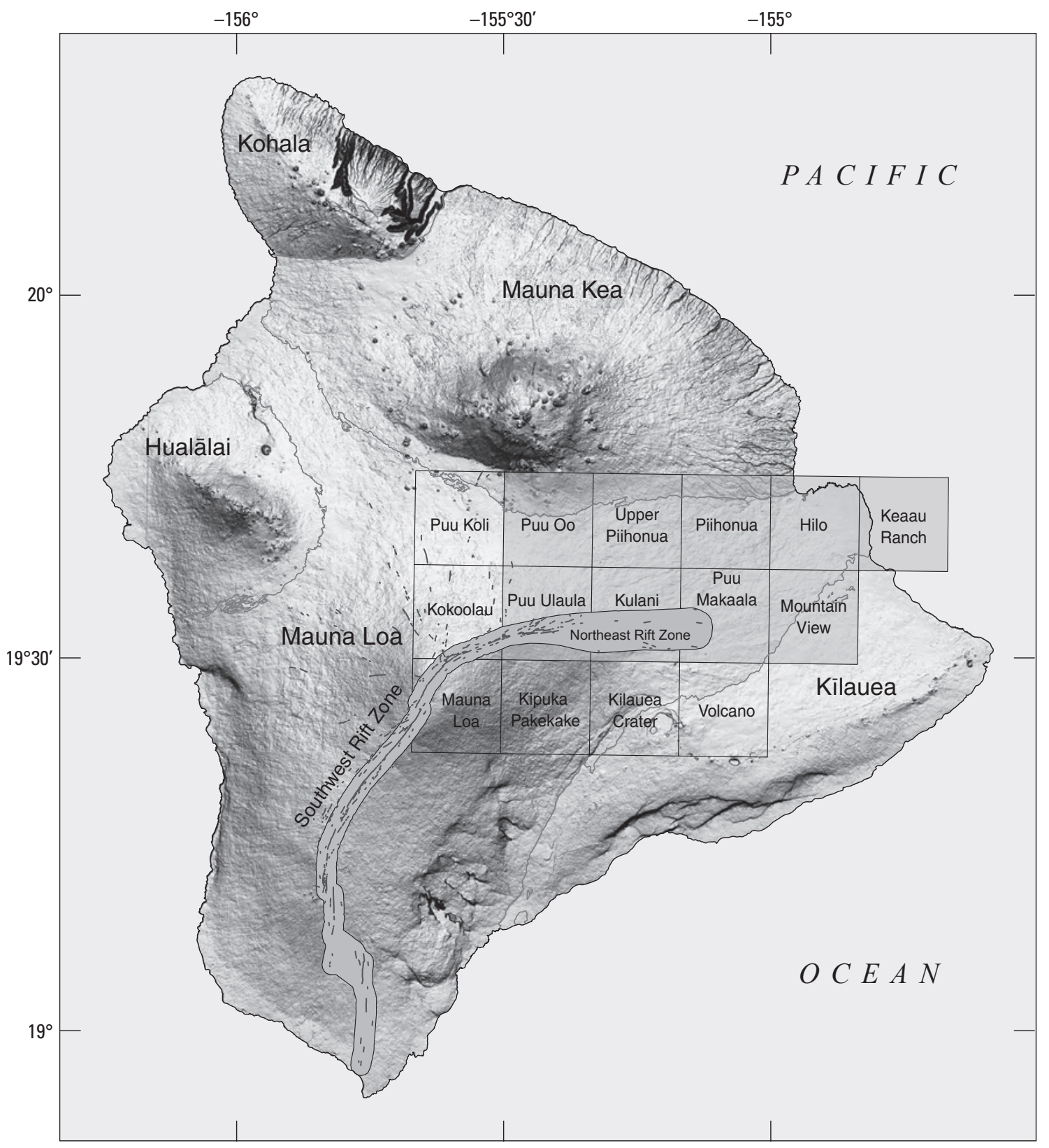

Figure 1. Map showing subaerial volcanoes forming Island of Hawai' i, fissures on Mauna Loa, and 7.5-minute topographic quadrangles in (shaded) and adjacent to map area. 
the Description of Map Units, as well as in the List of Map Units and the Correlation of Map Units on sheet 2. The database contains information on flow morphology, approximate age, exact age, mineralogy, data quality, unit names, and any existing overburden type. Access the database for this map at https://doi.org/10.3133/sim2932A.

\section{Acknowledgments}

A great many individuals have contributed to the body of knowledge that has made this geologic map possible. We thank Meyer Rubin and Jack McGeehin and those who have worked in their laboratory for radiocarbon age determinations. Duane Champion conducted the paleomagnetic studies to test correlations of several geologic units. Assistants in geologic mapping of the northeast flank include Lisa Peterson and Marjorie L. Summers. People who worked as archivists of the geologic samples and charcoal samples include Margery Summers, Toni Thompson, and Vicki Taylor. The digital database containing the geologic map was initially constructed by Sandi Margriter. Superintendents of Hawaii Volcanoes National Park permitted work on the northeast rift. We are grateful to Jane Buchanan-Banks for her geologic map of the Hilo quadrangle. Thorough and helpful reviews of the map and text by David Sherrod and Edward Wolfe resulted in many improvements in presentation.

\section{Geology}

\section{Northeast Rift Zone}

Although most Mauna Loa eruptions begin in the summit area (>12,000 ft [3,600 m] elev; Lockwood and Lipman, 1987), the Northeast Rift Zone (NERZ) was the source of eight flank eruptions since 1843 (table 1). The NERZ extends from the 13,680-ft-high (4,169 m) summit towards Hilo (population 60,000; second-largest city in State of Hawaii). Hilo is built entirely on flows erupted from the NERZ, although most source vents are more than $30 \mathrm{~km}$ distant. Most of these flows are older than A.D. 1843, but the A.D. 1880 flow extends into Hilo, nearly reaching Hilo Bay.

From the geologic record, we may deduce several generalized facts about the geologic history of the NERZ. The middle to uppermost segments of the rift zone were more active in the past 4,000 years than the lower portion of the rift zone. This may be due to buttressing of the lower east rift zone by Mauna Kea and Kilauea Volcano. The historical flows that erupted on the north side of the rift zone advanced toward Hilo. This flank of the volcano may be more vulnerable to inundation. Lockwood (1990) noted that the vents of historical activity are migrating to the south. The volcano appears to have a self-regulating mechanism that evenly distributes long-term activity across its flanks. The geologic record also supports this notion; the time prior to the historical period (Age Group 1, pre-A.D. 1843-1,000 yr B.P.) is dominated by activity on the south side of the NERZ.

The NERZ trends N. $65^{\circ} \mathrm{E}$. and is about $40 \mathrm{~km}$ long and 2-4 km wide, narrowing at the summit caldera. It becomes diffuse (6-7 km wide) at its downrift terminus, which is around $3,400 \mathrm{ft}(1,030 \mathrm{~m})$ elevation. Its constructional crest is marked by low-spatter ramparts and by spatter cones as high as $60 \mathrm{~m}$. Subparallel eruptive fissures and ground cracks cut vent deposits and flows in and near the rift crest. Lava typically flows to the north, east, or south, depending on vent location relative to the rift crest.

\section{Volcanic Deposits}

\section{Flows}

The map encompasses $1,140 \mathrm{~km}^{2}$ of the northeast flank (fig. 1) of Mauna Loa from 10,880 ft (3,786 m) elevation to sea level. It shows the distribution of eruptive units (flows) separated into 14 age groups ranging from a period prior to 30,000 yr B.P. to A.D. 1984.

Table 1. Summary statistics of historical (after A.D. 1843) eruptions on Mauna Loa's northeast flank, Island of Hawai'i, Hawaii.

[S, Summit; NE, Northeast Rift Zone; MKN, Moku‘āweoweo north (north flank). NA, not applicable; lava flows west]

\begin{tabular}{ccccccccc}
\hline Year & $\begin{array}{c}\text { Eruption } \\
\text { begins } \\
\text { (mo-day) }\end{array}$ & $\begin{array}{c}\text { Summit } \\
\text { activity } \\
\text { (days) }\end{array}$ & $\begin{array}{c}\text { Flank } \\
\text { activity } \\
\text { (days) }\end{array}$ & $\begin{array}{c}\text { Eruptive } \\
\text { area } \\
\text { of volcano }\end{array}$ & $\begin{array}{c}\text { Area } \\
\text { covered } \\
\left(\mathbf{k m}^{2}\right)\end{array}$ & $\begin{array}{c}\text { Volume } \\
\text { erupted } \\
\left(\mathbf{k m}^{\mathbf{3}}\right)\end{array}$ & $\begin{array}{c}\text { Error in est. } \\
\text { volume } \\
(\mathbf{\%})\end{array}$ & $\begin{array}{c}\text { Closest reach } \\
\text { to Hilo Bay/ } \\
\text { Komohana } \\
(\mathbf{k m})\end{array}$ \\
\hline 1984 & Mar-26 & $<1$ & 22 & S, NE & 48 & 0.220 & \pm 20 & $17.5 / 15.4$ \\
1942 & Apr-26 & 2 & 13 & S, NE & 34 & 0.176 & \pm 20 & $16 / 13.3$ \\
1935 & Nov-21 & 6 & 40 & S, NE, MKN & 33 & 0.087 & $\pm 20-40$ & $28.3 / 26.6$ \\
1899 & Jul-1 & 4 & 21 & S, NE & 23 & 0.081 & $\pm 20-40$ & $27 / 28.2$ \\
1880 & Nov-5 & 0 & 280 & NE & 51 & 0.130 & $\pm 20-40$ & $1.9 /-0.5$ \\
1855 & Aug-8 & $<1$ & $\sim 450$ & S, NE & 66 & 0.280 & $> \pm 40$ & $10.9 / 9.3$ \\
1852 & Feb-17 & 1 & 20 & S, NE & 33 & 0.182 & $\pm 20-40$ & $16.1 / 14$ \\
1843 & Jan-10 & 5 & $\sim 90$ & S, NE, MKN & 45 & 0.202 & $> \pm 40$ & NA \\
\hline Total & & & & & $\mathbf{3 3 3} \mathbf{k m}^{\mathbf{2}}$ & $\mathbf{1 . 3 5 8 \mathbf { k m } ^ { 3 }}$ & & \\
\hline
\end{tabular}


Pāhoehoe is characterized by bulbous, smooth, and ropy surfaces, and the general topography can be described as hummocky. Lava tubes are common features in pāhoehoe flows.

Most ' $a$ 'ā flows also start as pāhoehoe flow types near the vents and transition to ' $\mathrm{a}$ 'ā downslope.

'A'à flows, which cover slightly more than half of the map area, are generally thicker and form broader units than pāhoehoe flows. 'A'ā flows are characterized by rubbly and (or) clinkery upper surfaces and have a rough texture; they are typically 3 to $15 \mathrm{~m}$ thick.

Effusion rates and slope influence lava morphology. High effusion rates, combined with steep slopes, usually generate 'a‘ā. Moderate to low effusion rates typically produce pāhoehoe. Not surprisingly, ' $a$ 'a $\mathrm{a}$ is abundant in the region, which has the highest effusion rates and some of the steepest slopes of any sector of Mauna Loa (Trusdell, 1995). The relation between high effusion rates and steep slopes has momentous implications for volcanic hazards and flow-advance rates, especially for the southwest flank of Mauna Loa.

Vesicles are present in both pāhoehoe and 'a'ā flows. In ' $a$ 'a flows, vesicles are generally fewer in number and volume $(<35 \%)$, irregularly distributed, commonly deformed and subangular in shape, and larger in size than in pāhoehoe flows. In contrast, vesicles in pāhoehoe flows are smaller, more abundant and voluminous (40-60\%), moderately distributed to well distributed, and spherical to subrounded. Some age groups are not represented on this map (age groups 7, 14, and 15).

\section{Age Groups}

The age groups are arbitrary boundaries created by the authors. They are broken down into 1,000-year intervals until the latter age groups. The larger age groups represent time periods greater than 1,000 years. The age groups are defined on the basis of radiocarbon years. Unless the flows are dated, the reliability of age determinations decreases with increasing age.

\section{Age Group 0 (Historical period: A.D. 1843 and younger)}

Lava erupted from A.D. 1843 to 1984 covers 19 percent of the map area. Eruptions occurred in 1843, 1852, 1855-56, $1880-81,1899,1935-36,1942$, and 1984. Soil or ash cover is absent except in forested areas, and surficial glass is common. Most lava flowed north and northeast from the NERZ.

A.D. 1984-The 1984 eruption began on March 26 and continued for 22 days. It was Mauna Loa's fifth longest historical NERZ eruption; the erupted volume is $220 \times 10^{6} \mathrm{~m}^{3}$. Much of the lava is ' $a$ ' $\bar{a}$. The vents were distributed along a $15-\mathrm{km}$ segment of the NERZ between 9,350 and 12,400 ft (2,850 and $3,780 \mathrm{~m}$ ) elevation. Most fissures are west of the map area at higher elevations. The main fissure is located at approximately $9,600 \mathrm{ft}(2,926 \mathrm{~m})$ elevation and is shown on the map. The flows from this eruption came within $7 \mathrm{~km}$ of the greater city limits of Hilo (Kaumana City).

A.D. 1942 - The eruption began at the summit on April 26. When it ended on May 9, a lava flow extended $26 \mathrm{~km}$ from the main vents at $9,350 \mathrm{ft}(2,850 \mathrm{~m})$ elevation and came within $5 \mathrm{~km}$ of Hilo. 'A'ā erupted near Mauna Loa summit road and extended to the northeast as far as Piihonua quadrangle. During this eruption, the local government tried a second time to divert Mauna Loa lava from its course toward Hilo by bombing; this was first attempted in 1935.

A.D. 1935-36-The 1935-36 eruption began near the summit on November 21. On November 27, a new vent opened on the north flank at $8,805 \mathrm{ft}(2,685 \mathrm{~m})$ elevation. This vent, at the west-central edge of the map, is orthogonal to the trend of the rift zone. During this eruption, local government first attempted to use bombing to divert the advancing flow.

A.D. 1899-The 1899 eruption began with a summit outbreak on July 1 . It was followed on July 5 by a flank eruption on the NERZ at 10,990 $\mathrm{ft}(3,350 \mathrm{~m})$ elevation, only $3 \mathrm{~km}$ west of the map area. The flank eruption, which lasted 18 days, produced about $80 \times 10^{6} \mathrm{~m}^{3}$ of lava; it was the least voluminous historical eruption on the NERZ, only one-third the size of the 1984 eruption.

A.D. 1880-81 - The eruption of 1880-1881 began on May 1 , when a small, short-lived eruption at Mauna Loa's summit heralded the beginning of an eruptive sequence that was followed 6 months later by a voluminous flank eruption, which would eventually threaten Hilo. The flank phase of the eruption began on November 5 . The outbreak was located at $11,000 \mathrm{ft}$ (3,353 m) elevation, about $1.5 \mathrm{~km}$ above Pu'u'ula'ula. High lava fountains fed an 'a'a flow that moved swiftly down the north flank (west of the map area). Another branch of the 'a'a flowed southeast, stopping within $1.5 \mathrm{~km}$ of Kîlauea Volcano. As fountains waned, a new vent opened downrift, about 450 $\mathrm{m}$ northwest of $\mathrm{Pu}$ ' $\mathrm{u}^{\text {'ula }}$ 'ula. From this new vent, lava simply oozed up from an earth crack and moved as pāhoehoe steadily northeastward. There was no major concern during the winter of 1880-81, because the flow moved slowly. By late March 1881, the flow came within $11 \mathrm{~km}$ of Hilo. By early June the flow was within $8 \mathrm{~km}$ of Hilo, and concern mounted. On June 26, the flow entered stream channels above Hilo and appeared to accelerate. By August 10, all forward progress ceased. The 1881 lava came within $1.9 \mathrm{~km}$ of Hilo Bay. Its terminus today is at the intersection of Mohouli and Pōpolo Streets.

A.D. 1855-56- The 1855-56 eruption began in August 1855 and continued for about 450 days. It was Mauna Loa's longest historical eruption. The eruption included many episodes of high fountaining and was characterized by highly variable rates of lava production. Most of the lava erupted is pāhoehoe with minor amounts of ' $a$ ' $\bar{a}$. A lava tube system never formed, but the flows, which attained a volume of $280 \times 10^{6} \mathrm{~m}^{3}$, came within $10 \mathrm{~km}$ of Hilo Bay. The vents were distributed along a $10-\mathrm{km}$ segment of the NERZ between 9,020 and $11,975 \mathrm{ft}(2,750$ and 3,650 m) elevation. The flow is exposed south of Saddle Road (Highway 200) at 5,000 ft $(1,524 \mathrm{~m})$ elevation and north of the road near 2,400 ft (732 m) elevation. Trees on this flow are taller and grow more densely than those on the 1880-81 flow, because the rougher surface holds more water and nutrients.

A.D. 1852 - The 1852 eruption began on February 17 and continued for 20 days. Much of the lava is ' $a$ ' $a$; the erupted 
volume is $182 \times 10^{6} \mathrm{~m}^{3}$. The vents were distributed along an 18-km segment of the NERZ, which is mostly buried by younger lava flows. The flows from this eruption came within $6 \mathrm{~km}$ of Hilo. The higher elevation vents are $8.5 \mathrm{~km}$ west of the map area.

A.D. 1843 - The 1843 eruption began on January 10 and continued for approximately 90 days. This eruption produced both ' $a$ 'ā and pāhoehoe. Surface relief on the 1843 ' $a$ 'a $\mathrm{a}$ flow is more than $8 \mathrm{~m}$, locally. The high-standing areas are large floating masses of cooled lava that were left behind as more fluid ' $a$ 'a continued to move around them. The eruptive sequence demonstrates a common situation: younger pāhoehoe covering older ' $a$ ' $\bar{a}$ of the same eruption. Erupted volume is about $202 \times 10^{6} \mathrm{~m}^{3}$. Vents were distributed along a 5-km segment of the NERZ; the lowest elevation vent is radial to the trend of the rift zone. Most of this unit, including the source vents, is $3.5 \mathrm{~km}$ west of the map area.

\section{Age Group 1 (pre-A.D. 1843-1,000 yr B.P.)}

Spatter and flows are typically slightly weathered and have negligible overlying soil or ash except in forested areas. Surficial black glass is commonly present. Sixteen of eighteen flows have radiocarbon ages. In contrast to flows of Group 0, these flows traveled primarily southward from the NERZ. Eruptions from this period cover approximately 13 percent of the map area.

\section{Age Group 2 (1,000-2,000 yr B.P.)}

Spatter and flows typically have some overlying soil or ash at lower elevations, and any surficial glass shows slight mechanical degradation and color lightening to gray hues. Six of ten flows have radiocarbon ages. Eruptions from this period cover nearly 28 percent of the map area.

\section{Age Group 3 (2,000-3,000 yr B.P.)}

Spatter and flows are mildly weathered, and surficial glass is locally preserved. One of nine flows has a radiocarbon age. Eruptions from this period cover nearly 5 percent of the map area.

\section{Age Group 4 (3,000-4,000 yr B.P.)}

Spatter and flows are moderately weathered, and surficial glass is preserved only in protected places. Two of nine flows have radiocarbon ages. Eruptions from this period cover nearly 7 percent of the map area.

\section{Age Group 5 (4,000-5,000 yr B.P.)}

Spatter and flows are moderately weathered, surficial glass is rare, and upper surfaces have moderate mechanical degradation. These flows commonly have as much as $0.4 \mathrm{~m}$ of overlying soil or ash, especially to the north adjacent to Mauna Kea and to the south in close proximity to Killauea. Two of nine flows have radiocarbon ages. Eruptions from this period cover less than 6 percent of the map area.

\section{Age Group 6 (5,000-6,000 yr B.P.)}

These rocks are becoming weathered and typically are covered with $0.2-0.3 \mathrm{~m}$ of ash or soil, especially at lower elevations. Two of nine flows have radiocarbon ages. Eruptions from this period cover less than 10 percent of the map area.

\section{Age Group 7 (6,000-7,000 yr B.P.)}

Flows dated 6,000-7,000 radiocarbon yr B.P. were not identified within the map area. It is possible that, with so many undated flows, one or two could fall into this age category. Lockwood (1995) reported that the absence of any dates of this range suggests that eruptive activity may not have occurred on Mauna Loa's flanks during this time interval. It is plausible that activity may have been limited to the summit (lava lake activity) or the volcano's submarine flanks (Lockwood, 1995).

\section{Age Group 8 (7,000-8,000 yr B.P.)}

The flows are moderately weathered; upper surfaces have open-vesicle texture and are broken, and red-orange surfaces occur at higher elevations. Tephra is beginning to accumulate in lowlying areas. This age group is represented by a single dated flow. Eruptions from this period cover less than 4 percent of the map area.

\section{Age Group 9 (8,000-9,000 yr B.P.)}

The flows are deeply weathered, showing red-orange surfaces at higher elevations; mechanical disintegration of upper surfaces is almost complete. Tephra is beginning to accumulate in low-lying areas. Three of five flows have radiocarbon ages. Eruptions from this period cover less than 1 percent of the map area.

\section{Age Group 10 (9,000-10,000 yr B.P.)}

These flows are found only at low elevations of the NERZ; they are buried by younger flows closer to eruptive vents. Tephra and soil fill low-lying areas; accumulations as thick as $0.50-1 \mathrm{~m}$ are common. Surface color approaches red. Three of four flows have radiocarbon ages. Eruptions from this period cover less than 4 percent of the map area.

\section{Age Group 11 (10,000-15,000 yr B.P.)}

These flows are found only at low elevations of the NERZ; they are buried by younger flows closer to eruptive vents. Flows have few if any original surfaces left. Upper surfaces are commonly stained red orange, probably due to hydration of glass. In the wet windward regions, the rock is weakened by chemical weathering and hammer impacts often leave a divot. Olivine is altered, yellowed, and (or) brown green and begins to look micaceous. Units of this age have 1-3 m of soil or ash cover. Groundmass is often a dull gray and looks cryptocrystalline but, in actuality, is partly altered. Five of nine flows have radiocarbon ages. Eruptions from this period cover less than 3 percent of the map area. 
Age Group 12 (15,000-20,000 yr B.P.)

These flows are found only at low elevations of the NERZ; they are buried by younger flows closer to eruptive vents. Flows have no original surfaces left. Upper surfaces are commonly stained red orange, probably due to hydration of glass. In the wet windward regions, the rock is mushy from chemical weathering; hydrated glass turns to clay. Olivine appears micaceous and (or) cloudy and is mostly altered. Units of this age have 2-4 $\mathrm{m}$ of soil and ash cover. Groundmass is altered and lined with alteration products (limonite). Eruptions from this period cover less than 2 percent of the map area.

\section{Age Group $13(20,000-30,000$ yr B.P.)}

These flows are found only at low elevations of the NERZ; they are buried by younger flows closer to eruptive vents. These flows are exposed just above Hilo, where they are overlain by as much as $6 \mathrm{~m}$ of ash. The flows have no remaining original surfaces. Boundaries between individual flows are blurred. In the wet windward regions, the rock is mushy and olivine phenocrysts are mostly altered and generally soft. Five flows have radiocarbon ages. Eruptions from this period cover less than 1 percent of the map area.

\section{Age Group 14 (30,000-100,000 yr B.P.)}

Flows with dates of 30,000-100,000 yr B.P. were not identified within the map area. Flows from Mauna Loa with ages of 43,030 and 37,430 yr B.P. were dated in the Hawaii State Drilling Project. These flows are sufficiently old that all exposures are buried by younger flows. On the south end of the island they are exposed in fault scarps, sea cliffs, and drainages around Nā'ālehu and in the Kahuku Pali. Where exposed, these flows are commonly overlain by as much as $6 \mathrm{~m}$ of ash.

\section{Age Group 15 (>100,000 yr B.P.)}

Flows with dates of $>100,000 \mathrm{yr}$ B.P. were not identified within the map area. These flows are exposed in fault scarps and drainages on the southern end of the island and in the Ninole Hills. The unit represents the oldest exposed rocks on Mauna Loa. These rocks are commonly overlain by as much as $6 \mathrm{~m}$ of ash and have no remaining original surfaces.

\section{Surficial Sedimentary Deposits}

We separated the man-made (unit $\mathrm{m}$ ) from naturally occurring deposits. Small alluvial deposits (unit Qal) are present in the NERZ. Other sedimentary deposits were too small and transient to map. Alluvial deposits chiefly consist of unconsolidated sand along the coast and pebble- to cobble-size gravel in drainages that occur locally within portions of the map area.

Several man-made artificial deposits (unit $\mathrm{m}$ ) are found near Kea'au below the old Puna Sugar Mill (now a power generation plant for Hawaiian Electric Company, Inc.). These deposits consist of mud and rock slurry from washing cane prior to processing. The slurry was emptied onto adjacent younger Mauna Loa lava flows in an attempt to make the land arable. This unit is only mapped where the underlying rocks cannot be identified.

\section{Volcanic Ash}

\section{Pahala Ash}

Pahala Ash includes beds of fallout and surge deposits that represent accumulation of deposits from numerous eruptions. Deposits include glassy ash and lapilli, now mostly altered to clay, crystals, and lithic fragments. Phenocryst abundance is difficult to estimate, owing to chemical decomposition, but ranges from aphyric to moderately porphyritic, with as much as 8 percent olivine and fewer plagioclase phenocrysts. It is found chiefly in the Punaluu, Naalehu, and Ka Lae quadrangles and in adjacent upslope areas, where it overlies lava flows ranging in age from 31,000 to 2,000 yr B.P.

Pahala Ash was described by Stone (1926), Stearns and Clark (1930), Wentworth (1938), Stearns and Macdonald (1946), Fraser (1960), Walker (1969), and Easton (1978). The term eventually came to be used for ashes from Kohala to Kalae at South Point. According to Easton (1987), Wolfe (oral commun., 1986) determined that the ash deposits of Kohala, Waimea, Hāmākua, and North Hilo were derived locally and are chemically distinct from ashes near Killauea and on the east flank of Mauna Loa. Pahala Ash is not mapped at the surface in the map area.

\section{Distal Tephra Deposits}

All ashes in the mapped area that are less than, and equal to, late Pleistocene (16,000 yr B.P.) are incorporated into the undivided tephras. Unit tn defines deposits north of the NERZ and unit ts defines those adjacent to, and south of, the NERZ. "Tephra" (tn or ts) is used as the unit identifier when a mostly Holocene ash deposit is of sufficient thickness to mask the underlying flow(s) or when the extent of the flow(s) cannot be mapped with a reasonable degree of certainty. Where we are able to map ash-covered flows $\leq 16,000 \mathrm{yr}$ B.P. in age with a high degree of certainty (see database for contact certainty), we show a + pattern.

There are two main subdivisions in this group: northern tephra and southern tephra. The tephras are comprised of beds of ashfall deposits in the map area. The northern tephra (tn, FID 996) is probably derived from Mauna Kea, and the southern tephra (ts, FID 959) is most likely from Kīlauea, although Mauna Loa cannot be excluded as a source.

The ash is a mixture of yellow-brown palagonite, rare vitric shards, Pele's hair, pumice, and olivine phenocrysts. It is derived from airfall deposits, weathered and reworked ash, and sediments. The ash is comprised mostly of sand and silt-sized fractions. Ancient soil horizons are present in some localities. The appearance of the ash is greatly influenced by climate. In dry areas, it is friable, in places compact, but it is mostly sandy, loose, and dusty. In higher-rainfall areas, the ash appears claylike and darker in color. 


\section{Radiocarbon Data}

Table 2 reports 112 radiocarbon ages from 48 lava flows (Kelley, 1979; Kelley and others, 1979; Rubin and others, 1987; Buchanan-Banks and others, 1989; Buchanan-Banks, 1993). Most are conventional ages analyzed by the U.S. Geological Survey laboratory in Reston, Virginia; in addition, four Accelerator Mass Spectrometer (AMS) ages were analyzed by other laboratories.

Carbonized roots, twigs, or vegetative litter formed most samples; rarely, unaltered wood was used. Some eruptive units have multiple ages (table 2 ) obtained by dating samples from two or more locations beneath the unit. In these cases, we report a weighted mean age, whereby each age is weighted by the inverse of its variance before averaging (a standard statistical method; for example, Taylor, 1982).

Each age was calibrated to calendar years using the CALIB 4.0 Radiocarbon Calibration Program (Stuiver and others, 1998). The calibrated ages are for two standard deviations. The age range in table 2 encompasses the entire age range of calendar ages possible for a given radiocarbon age. Symbols indicating quality show usefulness of age in stratigraphic interpretations. Meaningless ages are reported in the Appendix.

\section{DESCRIPTION OF MAP UNITS}

[Some unit exposures on the printed or plotted map are not labeled to avoid obscuring data; use unit color or the database (https://doi.org/10.3133/sim2932A) for unit identification. The simplified map unit label is not unique and provides quick access to flow morphology, flow age group, phenocryst mineralogy, and flow number in an age group (table 3, sheet 1); this non-unique unit label may be used for an entirely different unit on a different flank of Mauna Loa. We use the term "phenocryst" for any mineral $\geq 1 \mathrm{~mm}$ in maximum diameter. Pyroxene is not an abundant phenocryst in Mauna Loa lava flows and, therefore, it is not included in phenocryst mineralogy. Multiple labels for a unit are listed with the most abundant lithology first. In addition to the map unit label, a unique, three-digit flow identification number (FID; for example, FID 831) is assigned to each mapped flow unit to facilitate use of the database for the entire Mauna Loa edifice; therefore, the FID is essential as a unique descriptor for unit identification in the database. No age group 7,14 , or 15 units were identified in the map area]

\section{SEDIMENTARY DEPOSITS}

\section{SURFICIAL DEPOSITS (HOLOCENE)}

Qal

Unconsolidated sedimentary deposits - Include alluvium, beach- and bay-filling deposits, gravel, and sand

$\mathrm{m}$

Man-made deposits-Artificial fill found $1.5 \mathrm{~km}$ northeast of Kea' au and on northeast corner of General Lyman Field (Hilo International Airport). Deposits consist of mud, rock slurry, sugarmill effluent deposits, and artificial fill. Mapped only where underlying rock cannot be identified

\section{VOLCANIC DEPOSITS}

\section{LAVA FLOWS AND VENT DEPOSITS}

\section{Kau Basalt}

The Kau Basalt includes historic and prehistoric members. The prehistoric units range in age from pre-A.D. 1843 to 30,000 yr B.P. The Kau Basalt consists of tholeiitic basalt, vent deposits, and lava flows. The flows are mostly aphanitic, and some have variable amounts of olivine and plagioclase phenocrysts. Pyroxene is rare in hand specimen. Most of the map units are members of the Kau Basalt.

\section{Age Group 0 (A.D. 1843 and younger; Holocene)}

a0a1, p0a1, A.D. 1984 flow-Aphanitic 'a'ā with $<1 \%$ olivine phenocrysts $1-2 \mathrm{~mm}$ in size. Vents were distribs0a1 uted along 15-km segment of NERZ between 9,350- and 12,400-ft elev. Most fissures are west of map area at higher elevations. FID 783

a0a2, s0a2 A.D. 1942 flow-Massive 'a'ā containing $<1 \%$ olivine phenocrysts and abundant plagioclase microphenocrysts in a microcrystalline groundmass. Distinguished from A.D.1984 flow by abundant plagioclase microphenocrysts. 'A ‘a erupted near Mauna Loa access road and flowed northeast as far as Piihonua quadrangle. FID 784

p0a3, a0a3 A.D. 1935-36 flow-Flow is aphanitic with fine crystalline groundmass. Toothpaste 'a'ā flow, commonly mixed with slabby pāhoehoe, in southwest corner of Puu Oo and Upper Piihonua 
a0a4, p0a4, s0a4

p0b5, a0b5, s0b5

p0j6, a0j6, s0j6

a0e7, p0e7, s0e7

a0k8, p0k8

a1g1, p1g1

a1k2, m1k2, p1k2, s1k2

p1k3, a1k3

a1a4, p1a4

a1a5, p1a5, s1a5

a1j6, p1j6, s1j6, m1j6

m1a7, p1a7

a1i8, s1i8, p1i8 quadrangles. Vesicles are subrounded and may be lined with magnesioferrite. 'A 'à near Hwy 200 in saddle between Mauna Loa and Mauna Kea is generally covered with light-gray lichen. Vent at west-central edge of map is orthogonal (radial) to trend of rift zone. FID 785

A.D. 1899 flow - Nearly aphanitic 'a'a contains fine crystalline groundmass with $<1 \%$ olivine phenocrysts and $1-3 \%$ plagioclase microphenocrysts. Found along Mauna Loa summit road in Puu Ulaula and Puu Oo quadrangles. Eruption began with a summit outbreak followed by a flank eruption on NERZ at 10,990-ft elev, only $3 \mathrm{~km}$ west of map area. FID 786

A.D. 1880-81 flow-Flow is fresh and glassy, with 1-3\% clear olivine phenocrysts and abundant, inconspicuous plagioclase microphenocrysts. Both ' $a$ 'ā and pāhoehoe morphologies found. FID 787

A.D. 1855-56 flow- 'A'ā, pāhoehoe, and spatter morphologies present. Contains 2-8\% clear subhedral olivine and $1-5 \%$ plagioclase phenocrysts. Trees on this flow are taller and grow more densely than those on 1880-81 flow. FID 788

A.D. 1852 flows - A predominantly picritic 'a'ā with minor pāhoehoe, erupted from several vents along upper NERZ. This eruption is noteworthy for its bimodal distribution of olivine phenocrysts. Earlier vents at higher elevation (outside map area) tend to have more spatter and to erupt olivine-poor $(<<1 \%)$ lava; whereas, lower-elevation vents have $15-20 \%$ olivine in a fine crystalline groundmass. FID 789

A.D. 1843 flow-Spiny 'a'ā north of summit of Mauna Loa, in and west of Puu Oo quadrangle. Most of unit is exposed west of map area. Flow has 1-3\% brownish-green olivine phenocrysts and $8-10 \%$ plagioclase phenocrysts. Some olivine is present as discrete crystals; others are intergrown with plagioclase. This eruption produced both ' $a$ 'a and pāhoehoe. Surface relief on ' $\mathrm{a}$ 'a flow is $>8 \mathrm{~m}$ locally. Lowest elevation vent is oblique to trend of rift zone. FID 790

Age Group 1 (pre-A.D. 1843-1,000 yr B.P.; Holocene)

Ke'āmoku Kīpukakēkake flow-Dense, fine-grained, transitional from pāhoehoe to 'a‘ā in Kulani and Puu Ulaula quadrangles. Groundmass is sparkly, dark, and feldspathic. Small olivine phenocrysts $(<1 \%)$ are widely scattered; $1-2 \%$ plagioclase is present as fine laths. Age, $288 \pm 36$ radiocarbon yr B.P. FID 800

Pu'ukupanaha flow-Mixed, dense pāhoehoe and spiny 'a ā flow in Puu Oo and Puu Ulaula quadrangles. Flow has vesicle-poor, gray groundmass and contains 1-2\% clear, subrounded olivine phenocrysts and 1-8\% fine, inconspicuous plagioclase. Eruption fissure is arcuate; its trend strays from northeast to nearly due north at its distal end. Age, $300 \pm 50$ radiocarbon yr B.P. FID 796

Kīpukamauna'iu flow_Pāhoehoe in contact with and south of $\mathrm{Pu}$ 'u'ula'ula. Contains dense, well-crystallized, feldspathic groundmass. Surface is medium gray to black. Flow tops, locally glassy, are mostly weathered; surface glass is broken up. Flow contains $0-1 \%$ small olivine phenocrysts and $1-8 \%$ anhedral laths and clots of plagioclase, commonly intergrown with olivine. Vesicles are subrounded, commonly distorted, and may be lined with magnesioferrite. Age, $311 \pm 25$ radiocarbon yr B.P. FID 801

Kīpuka within A.D. 1899 flow field — Aphanitic 'a'ā near west boundary of Puu Ulaula quadrangle; probable source vent buried near 10,600-ft elev. Dense, medium-gray, nearly flinty groundmass with 10-15\% subangular magnesioferrite-lined vesicles. FID 803

'Āinahou flow-Dense pāhoehoe to vesicular 'a'ā in Puu Ulaula, Upper Piihonua, and Puu Oo quadrangles. Well-crystallized, bluish-gray, feldspathic groundmass with 0-1\% light-green olivine phenocrysts and microphenocrysts of plagioclase. Age, $410 \pm 60$ radiocarbon yr B.P. FID 792

Kūlani picrite flow—Dense 'a'ā with rare pāhoehoe in Kulani, Puu Ulaula, and Puu Makaala quadrangles. Origin is vent named Pu'uha'a at 9,200-ft elev. Contains 5-20\% large, clear, olivine phenocrysts and $2-8 \%$ fine plagioclase as laths or clots. Some plagioclase forms radiating intergrowths with olivine. Gabbroic xenoliths are rare to abundant. Vesicles, 6-8\%, are subrounded to subangular. Age, $437 \pm 46$ radiocarbon yr B.P. FID 793

Ke A Po'omoku flow-Massive pāhoehoe and 'a'ā that flooded Mauna Loa's flank northeast of caldera and southeast of rift zone. Eruptive fissures extend into NERZ and northwest of map area. Contains $<1 \%$ olivine phenocrysts in medium-gray, fine-grained feldspathic groundmass. Age, $475 \pm 41$ radiocarbon yr B.P. FID 274

Mauna Loa Boys School flow-Mostly 'a'ā and minor pāhoehoe in Puu Ulaula and Kulani quadrangles. Contains $4-5 \%$ large olivine phenocrysts; $2-3 \%$ plagioclase laths, mostly intergrown 


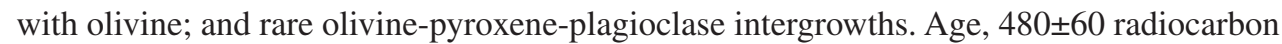
yr B.P. FID 794

p1g9, a1g9 Ke‘āmoku Kīpukakulalio flow—Dense, dark-gray, nearly aphanitic 'a‘ā in Puu Ulaula quadrangle. Flow contains $<1 \%$, widely scattered olivine phenocrysts and $2 \%$ plagioclase phenocrysts. Age, $569 \pm 53$ radiocarbon yr B.P. FID 802

p1a10 Kulaloa flow-Aphanitic pāhoehoe; source vent may be in Kulani quadrangle but has not been found. Found only below 4,800-ft elev; vent was probably a fissure at about this elevation. Flow traverses Kulani, Puu Makaala, Piihonua, and Hilo quadrangles. Buried upslope by unit a1j6 (FID 793), which is fairly narrow. Unlikely that narrow overlying flow fortuitously covered all upslope exposures of Kulaloa flow. Contains fresh glass and uniform, spherical vesicles. Age, $570 \pm 60$ radiocarbon yr B.P. FID 791

m1k11, a1k11，Ke'āmoku Kīpukakulalio east flow_Tube-fed pāhoehoe with some 'a‘ā, in Puu Ulaula and p1k11, s1k11 Kulani quadrangles. Glass is fresh where protected from mechanical weathering. Contains $2-6 \%$ olivine phenocrysts and 5-10\% plagioclase as laths, clumps, and intergrowths with olivine. Vesicles are mostly rounded and coated with magnesioferrite. Hosts some of most spectacular tube systems with skylights on northeast side of Mauna Loa. Tree molds are exposed along $\mathrm{Pu}$ 'u Oo Volcano Trail where not covered by ash. Abundant charcoal samples can be found where flow overlies unit a5b7 (FID 870). Age, 575 \pm 38 radiocarbon yr B.P. FID 799

a1j12, p1j12, s1j12, m1j12

p1113, a1113

p1b14, m1b14

a1l15, s1l15

p1e16, m1e16, s1e16, a1e16

p1a17

m1i18, a1i18, p1i18

p2a1, a2a1

a2l2, p2l2, s2l2
Keawewai Camp flow-Weathered 'a'a flow, which has lost most surface glass, is in Puu Ulaula and Kulani quadrangles. Variable mineralogy; $0-10 \%$ olivine phenocrysts and 2-3\% plagioclase laths. Contains rare, small, rounded gabbroic xenoliths. Age, $590 \pm 50$ radiocarbon yr B.P. FID 797

Keauhou Ranch flow — Large tube-fed pāhoehoe and minor 'a'ā on Keauhou Ranch in Kulani quadrangle. The 6-20\% olivine forms phenocrysts and microphenocrysts; 4-6\% plagioclase

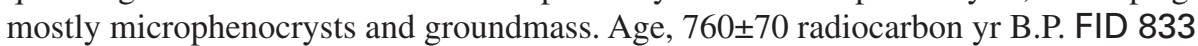

Flow north of southeast A.D. 1880 lobe-Mixed 'a'ā and pāhoehoe flows southeast of

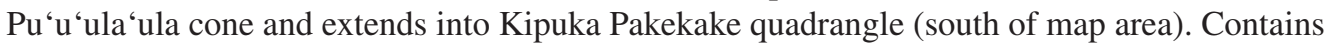
$4 \%$ inconspicuous round olivine phenocrysts. Age, $780 \pm 70$ radiocarbon yr B.P. FID 840

'Ōla'a Uka flow-In Kulani quadrangle, this 'a'a a flow is covered by rich soil (ash deposit) that supports 'ōhi'a, hāpu'u, and koa forest so dense that it betrays the young flow age. Soil/ash source is probably alluvium washed in from older surrounding units. Contains 3-10\% anhedral olivine phenocrysts and $8-15 \%$ plagioclase phenocrysts. Sugary intergrowths of olivine and plagioclase form 5-12\% of rock. Age, $880 \pm 60$ radiocarbon yr B.P. FID 795

Pu'uwāhi picrite flow—Dense picrite straddling NERZ in Puu Ulaula quadrangle near Pu 'u 'ula 'ula cone. Spatter and reticulite are $750 \mathrm{~m}$ northeast of Pu'u'ula 'ula. Pāhoehoe and 'a'ā with medium-gray groundmass, containing 10-20\% clear, fresh olivine phenocrysts as much as $6 \mathrm{~mm}$ across. Weathered surfaces are orange brown with protruding olivine minerals. Age, $955 \pm 24$ radiocarbon yr B.P. FID 837

Flow 839 — Aphanitic pāhoehoe, found isolated within 1935-36 flow in Puu Oo quadrangle and farther west. Dense and well crystallized, with thick covering of surface glass as much as $5 \mathrm{~mm}$ thick. Vesicles are spherical and uniform size. FID 839

Ke'āmoku Kīpukakulalio west flow—Both pāhoehoe and 'a'ā in Puu Ulaula quadrangle. Flow contains $3-8 \%$ subhedral, sugary olivine phenocrysts and $0-2 \%$ plagioclase phenocrysts. Vesicles are subrounded to elongate and may be magnesioferrite lined. FID 838

$$
\text { Age Group } 2 \text { (1,000-2,000 yr B.P.; Holocene) }
$$

Kūkūau flow_Tube-fed, nearly aphanitic pāhoehoe and rare 'a'ā in Puu Ulaula, Puu Makaala, Upper Piihonua, Piihonua, and Hilo quadrangles. Contains well-crystallized groundmass, $0-2 \%$ olivine phenocrysts, and $<1-2 \%$ very fine plagioclase microphenocrysts. Groundmass has wellsorted spherical vesicles, which may have diktytaxitic, magnesioferrite-lined cavities. Some vugs are $3 \mathrm{~cm}$ diameter and lined with plagioclase and clinopyroxene. Flowed within $1 \mathrm{~km}$ of Hilo Bay. Age, 1,333 \pm 26 radiocarbon yr B.P. FID 829

Pana'ewa picrite flow-Widespread, vesicular, olivine- and plagioclase-rich 'a'ā and pāhoehoe in Kulani, Puu Makaala, Mountain View, and Hilo quadrangles. Lava erupted from a cinder cone at 6,020-ft elev. Flow has wide range of modal mineralogy. Large, euhedral, light-green olivine phenocrysts (2-20\%) are as large as $7 \mathrm{~mm}$. Contains $5-15 \%$ clots and rare laths of plagioclase occurring as phenocrysts and microphenocrysts. Sparse gabbroic 
a2b3, s2b3, p2b3, m2b3

a2k4, p2k4, m2k4, s2k4

p2k5, a2k5, s2k5

p2b6, a2b6, s2b6, m2b6

p2g7, a2g7

a2d8

p2h9

a2d10

p3b1

a3g2, p3g2, m3g2 microxenoliths are found locally. Groundmass is well crystallized and light bluish gray. Large, subangular to spherical vesicles form 30-40\% of groundmass and are lined with magnesioferrite, which is unaltered or stained red. Flow is commonly covered with brown soil. Reticulite as much as $0.4 \mathrm{~m}$ thick from this eruption mantles older units downwind of vent. This flow is the most voluminous and widespread unit in map area. It covers $173 \mathrm{sq} \mathrm{km}$ and forms coastline from Hā'ena (Shipman's Estate) to Bayfront (Hilo Bay). Age, 1,470 \pm 50 radiocarbon yr B.P. FID 828

Flow 830 - Mixed 'a'ā and minor pāhoehoe flow in Puu Ulaula, Upper Piihonua, and Kulani quadrangles. Contains subrounded vesicles; $2 \%$ clear, subhedral, olivine phenocrysts; and groundmass full of anhedral plagioclase microlites. Erupted from fissures oblique to rift zone at 9,760-8,800-ft elev. FID 830

Upper Waiākea flow—Mixed pāhoehoe and 'a‘ā flows in Puu Ulaula, Puu Makaala, Piihonua, and Kulani quadrangles. Lava contains $0-2 \%$ olivine phenocrysts, commonly as intergrowths with plagioclase, and 5-12\% very fine plagioclase as laths and blebs. Vesicles are subrounded, elongate, and commonly magnesioferrite lined. ' $\mathrm{A}$ ' $\mathrm{a}$ is crumbly and weathered to yellow orange. Flow is covered with thin to thick layer of soil and ash; consequently, outcrops range from abundant to rare. This eruption sent flows over both sides of rift zone. Age, 1,638 \pm 32 radiocarbon yr B.P. FID 864

Pu'ukāhilikū flow_'A 'ā and pāhoehoe flows in Puu Oo, Upper Piihonua, and Puu Ulaula quadrangles. Originates from two discontinuous radial vent fissures upslope and one fissure vent on top of Pu'uhuluhulu (Mauna Kea Cone). First fissure erupted lava from 7,820-ft elev; second, lower fissure is found at 7,360-ft elev. The third fissure has been removed by quarrying activites and is represented by a dike within and two remnant ' $a$ 'a flows flanking the cone on the west side. Flow contains $0-2 \%$ anhedral, dark-green olivine and 2-8\% anhedral plagioclase phenocrysts. Conspicuous intergrowths of olivine and plagioclase are present and form 1-2\% of rock. Groundmass is light gray and feldspathic, with diktytaxitic vugs. Subrounded to subangular vesicles form large, open pockets at surface and may be magnesioferrite lined. Many outcrops exposed, although most surfaces are covered with soil supporting scattered 'ōhi'a trees as tall as $20 \mathrm{~m}$. Age, 1,838 94 radiocarbon yr B.P. FID 866

'Āinakahiko flow- 'A'ā and pāhoehoe commonly in small isolated patches surrounded by younger flows in Puu Oo and Puu Ulaula quadrangles. Large exposure in central Puu Oo quadrangle. Flow is very sparsely phyric, with approximately $1 \%$ olivine phenocrysts and $0-2 \%$ plagioclase microphenocrysts. Groundmass is light gray, with some diktytaxitic and open vug textures. Vesicles are elongate, round, and subangular. Surface is broken and weathered to reddish, tan, or orange. Black lichen commonly present on surface. Age, 1,880 \pm 200 radiocarbon yr B.P. FID 867

Upper Strip Road flow-Minor ' $a$ 'ā and extensive pāhoehoe and related tube system, characterized by bulbous toes, south of $\mathrm{Pu}$ 'ukulua in Puu Ulaula quadrangle. Contains $<<1 \%$ olivine phenocrysts and $\sim 2 \%$ plagioclase as microphenocrysts and phenocrysts. Vesicles are spherical to subrounded. Age, 1,993 \pm 43 radiocarbon yr B.P. FID 883

Flow 834-Small unnamed flow near west edge of Kulani quadrangle, west of Solomons Waterhole. Unit is olivine-rich ' $a$ 'ā that contains $10-15 \%$ olivine and is quite vesicular for ' $a$ 'ā. FID 834

Flow 832 - Tiny kīpuka of pāhoehoe surrounded by flow a1k11 (FID 799) in southwestern Kulani quadrangle. Contains $8-10 \%$ large plagioclase phenocrysts as much as $3 \mathrm{~mm}$ across. No glass present, yet ropy surfaces are preserved. No significant soil and ash accumulation. FID 832

Flow 831 - 'A'à within Kulani and Puu Makaala quadrangles, south of Kūlani Cone Complex. Olivine rich and highly vesicular. Contains $12-16 \%$ large olivine phenocrysts, commonly oxidized. FID 831

$$
\text { Age Group } 3 \text { (2,000-3,000 yr B.P.; Holocene) }
$$

Solomons Waterhole flow-Tube-fed pāhoehoe in Kulani quadrangle, north of Kūlani Cone and south of Pu'ukīpū. Groundmass is light gray, well crystallized, and feldspathic. Contains 0-8\% olivine phenocrysts and scattered plagioclase as microlaths. Outcrops are obscured by soil that supports a mature 'ōhi 'a forest. Age, 2,550 80 radiocarbon yr B.P. FID 874

Flow 836 - Loose slabby 'a 'ā west of A.D. 1880 flow, in Puu Ulaula quadrangle, that flowed in southeasterly direction. Contains dark-gray groundmass that is flinty because of abundant fine plagioclase microlites. Vesicles are subangular to subrounded. Weathered surfaces are tan orange. FID 836 
p3|3, a3|3

s3g4, a3g4

m3a5, s3a5, p3a5

a3h6

p3i7, a3i7, s3i7, m3i7

a3g8, s3g8

a3a9, m3a9, p3a9

p4a1, a4a1

$\mathrm{p} 4 \mathrm{f} 2, \mathrm{a} 4 \mathrm{f} 2$, $\mathrm{m} 4 \mathrm{f} 2$, s4f2

a4|3

a4a4, p4a4

a4h5, p4h5

p4a6, a4a6
Flow 865-Mixed pāhoehoe and 'a 'ā in central Upper Piihonua and Piihonua quadrangles. Found between A.D. 1855-56 and A.D. 1880 flows. Groundmass is well crystallized and dense. Unit contains $2-8 \%$ yellow, anhedral olivine phenocrysts and $8-10 \%$ fine anhedral plagioclase. FID 865

Pu'u 7996-Spatter and cinder cone and minor ' $a$ 'ā at 7,996-ft elev on NERZ in Puu Ulaula quadrangle. Contains $<1 \%$ olivine, commonly intergrown with plagioclase, and $1 \%$ plagioclase microphenocrysts and phenocrysts. Groundmass is well crystallized and full of plagioclase microlites. FID 896

Flow 888-Mixed flow of pāhoehoe and 'a'à (west of Pu'ukupanaha; a1k2, FID 796) in Puu Ulaula quadrangle. Nearly aphanitic with inconspicuous plagioclase microphenocrysts. Weathers to yellow-tan-gray color. Contains rare gabbroic microxenoliths. FID 888

Flow 885-Dense 'a'ā looks fresher than Upper Waiākea 'a'ā (a2k4, FID 864) in Puu Ulaula and Kulani quadrangles near central part of shared boundary, sandwiched between two southernmost lobes of A.D. 1984 flow. Contains 10\% fine plagioclase laths as large as $0.5 \mathrm{~mm}$. FID 885

Flow 884-Dense, weathered 'a'ā and tube-fed pāhoehoe in southeast corner of Puu Ulaula and southwest corner of Kulani quadrangles. Contains dark-gray groundmass, 2-5\% olivine phenocrysts, and 1-2\% plagioclase as microphenocrysts and rare phenocrysts. Vesicles are subangular to subrounded and may be magnesioferrite lined. Surface is broken and weathered red. FID 884

Flow 881-Dense, red-stained 'a'à $4.3 \mathrm{~km}$ east-southeast of Pu'u'ula'ula cone. Flow has 4-5\% plagioclase microphenocrysts and phenocrysts in fine-grained sparkly groundmass. FID 881

Flow 894-Kīpuka between most downrift part of A.D. 1942 flow and main lobe of A.D. 1984 fissure in Puu Ulaula quadrangle. Contains mildly feldspathic, medium-gray groundmass. Contains $<1 \%$ olivine-plagioclase intergrowths and $<1 \%$ each of olivine and plagioclase phenocrysts. FID 894

$$
\text { Age Group } 4 \text { (3,000-4,000 yr B.P.; Holocene) }
$$

Punahoa flow - Widespread, nearly aphanitic, tube-fed pāhoehoe and rare 'a'ā in Upper Piihonua, Piihonua, Kulani, and Hilo quadrangles. Groundmass varies from diktytaxitic to flinty. Contains $<1 \%$ olivine phenocrysts and fine plagioclase microlites. Vesicles are subrounded to spherical, uniformly sized, locally magnesioferrite lined, and commonly weathered to red. Covered with thin soil 5-8 cm thick. Bogs are common in western Piihonua quadrangle. Dense 'ōhi'a forests with much 'ōhi 'a dieback are common. Age, 3,404 \pm 25 radiocarbon yr B.P. FID 863

Kīpuka 'Āinahou flow—Mixed pāhoehoe and 'a'ā in Puu Oo, Upper Piihonua, and Puu Ulaula quadrangles. Content of subhedral to euhedral olivine phenocrysts ranges from 15-25\% in center of flow to 4-6\% near surface. Vesicles are subangular to spherical, poorly to moderately sorted, and include rare pipe vesicles. In contrast to thick 'ōhi'a forests on adjoining flows, this unit characteristically supports thick stands of brushy pūkiawe and open canopies of koa trees, probably owing to climatic conditions and past disturbance of forest by fire. Age, $3,433 \pm 44$ radiocarbon yr B.P. FID 868

Flow 882 - 'A $A \bar{a}$ in southeast corner of Puu Ulaula quadrangle. Contains $8-12 \%$ olivine phenocrysts, $8-15 \%$ plagioclase phenocrysts, and 5-6\% olivine-plagioclase intergrowths. Plagioclase is more conspicuous than olivine. Covered by layers of yellow ash, probably from Kîlauea, in low-lying areas. FID 882

Flow 878- 'A'ā flow and pāhoehoe in southeastern Puu Oo and southwestern Upper Piihonua quadrangles, surrounded by A.D. 1880-81 flow. Dark-gray groundmass. Contains $<1 \%$ olivine and $1-2 \%$ plagioclase laths, both as microphenocrysts. Flow surface has many round lava balls as much as $0.5 \mathrm{~m}$ across. Weathered surfaces range from shades of gray to orange. FID 878

Flow 873-'A'ā flow with minor pāhoehoe in north-central Puu Ulaula quadrangle, sandwiched between A.D. 1855-56 and A.D. 1880-81 flows. Pāhoehoe is slabby and crunchy. 'A 'ā is dense and almost nonvesicular, with light-gray, feldspathic groundmass. Vesicles are subrounded to subangular. Contains 0-1\% olivine phenocrysts, commonly intergrown with plagioclase, and 5-8\% fine-grained, conspicuous plagioclase laths. Surfaces are severely broken, weathered, and covered with orange-yellow clay (altered tephra). FID 873

Flow 879-Aphanitic 'a'ā and pāhoehoe exposed in a kīpuka within the Kīpukamauna'iu flow (p1k3, FID 801) 200 m southwest of Pu'u'ula 'ula cone. Contains mildly feldspathic groundmass. FID 879 
m4j7, a4j7 Lava north of Keawewai Camp-Olivine-rich pāhoehoe and 'a'ā flow north of Keawewai Camp in Kulani quadrangle. Contains 3-20\% (avg 8\%) olivine phenocrysts. Minor, sugary plagioclase microphenocrysts, as intergrowths with olivine, form $0-3 \%$ of rock. Covered by moderate amount of soil and ash. Unusually fresh glass for a flow of this age is found in some localities, probably preserved by ash cover. FID 875

p4g8, a4g8, $\quad$ Flow 877-'A'ā and pāhoehoe between A.D. 1880-81 and A.D. 1942 flows in central Puu Ulaula s4g8 quadrangle and ' $a$ ' $\bar{a}$ in northwest corner of Kulani quadrangle northeast of distal end of A.D. 1852 flow. Contains 0.5-1\% scattered, subhedral, very fine, clear olivine in a light-gray, feldspathic, groundmass. Felt-like groundmass with anhedral plagioclase microlites makes plagioclase abundance $\sim 5 \%$. Vesicles mostly angular but tend toward rounded in center of flow core. 'Ōhi'a trees as tall as $6 \mathrm{~m}$. FID 877

m4a9, p4a9, a4a9

Flow 895- 'A ' 'ā and pāhoehoe flows originate from spatter ramparts uprift of $\mathrm{Pu}$ 'u'ula 'ula cone in Kokoolau quadrangle (west of map area). Represents only flows found in Puu Ulaula quadrangle. Nearly aphyric, with rare phenocrysts of olivine and plagioclase. Groundmass is medium gray, microcrystalline, and mildly feldspathic with abundant plagioclase microlites. A very large tube system lies within pāhoehoe. Surface is tan. FID 895

$$
\text { Age Group } 5 \text { (4,000-5,000 yr B.P.; Holocene) }
$$

p5a1, a5a1 Wilder Road flow_Nearly aphanitic pāhoehoe flow in Upper Piihonua, Kulani, Piihonua, and Hilo quadrangles. This lengthy flow, found between A.D. 1942 and A.D. 1984 flows, has <1\% subhedral olivine phenocrysts in well-crystallized, fine-grained, plagioclase-rich groundmass. Age, $4,173 \pm 21$ radiocarbon yr B.P. FID 954

a5a2, p5a2 Waiakeawaena flow_Dense 'a'ā with minor amounts of pāhoehoe in Upper Piihonua quadrangle. Contains dark groundmass that appears aphanitic when wet. Sparse, subhedral, clear olivine phenocrysts form $0.5-1 \%$ of rock; plagioclase microphenocrysts form $1-2 \%$. Characterized by great local relief (1-2 m), large 'a'ā blocks, and patchy soil cover. Age, 4,695 \pm 58 radiocarbon yr B.P. FID 876

p5a3, m5a3, $\quad$ Flow 880 — Aphanitic pāhoehoe and dense, fluid 'a'ā flow $2 \mathrm{~km}$ south of Pu'u'ula'ula cone intera5a3

a5b4

$\mathrm{m} 5 \mathrm{j} 5, \mathrm{p} 5 \mathrm{j} 5$ fingers with A.D. 1880-81 flow. Contains medium-gray, feldspathic groundmass that sparkles. Flow is characterized by well-crystallized, flinty groundmass. FID 880

Flow 870 - 'A ' $\bar{a}$ and slabby, with minor tube-fed pāhoehoe in southwestern Kulani quadrangle. In contact with and isolated by Ke'āmoku Kīpukakēkake flow (a1g1, FID 800). Rare toothpaste and ' $a$ ' $\bar{a}$ phases exist in southernmost reach of flow. Contains $0-2 \%$ widely scattered olivine phenocrysts in gray, feldspathic groundmass. Soil/ash coverage is nearly continuous. FID 870

Flow 869-Mixed 'a'ā and pāhoehoe surrounding Kūlani Cone in Kulani quadrangle. Contains $3-7 \%$ scattered, large, clear olivine phenocrysts and 0-4\% plagioclase as phenocrysts and fine laths in feldspathic groundmass. Vesicles are subrounded to subangular and lined with magnesioferrite. Commonly covered with deposits of soil and ash ranging from several centimeters to $0.5 \mathrm{~m}$ thick. Covered by reticulite and tephra of Pana'ewa picrite flow (s2I2, FID 828) downwind from Kūlani Cone. FID 869

s5g6, p5g6 Pu'u 8400_-Spatter and tephra cones at 8,400-ft and 8,600-ft elev on NERZ near contact of A.D. 1942 and A.D. 1984 flows. Contains 1-2\% scattered plagioclase laths and phenocrysts; plagioclase ranges from 1 to $2 \mathrm{~mm}$ long. Groundmass is dark gray and flinty. FID 898

$\mathrm{m} 5 \mathrm{~b} 7, \mathrm{p} 5 \mathrm{~b} 7$, a5b7, s5b7

Flow 972-Mixed 'a 'ā and pāhoehoe flow units in north-central Puu Ulaula quadrangle between A.D. 1855 and A.D. 1880-81 flows. Unit characterized by 1-2\% subhedral and clear olivine phenocrysts. Well-developed tube and channel system. Upper surface color is orange tan. FID 972

s5b8

a5a9, s5a9

$\mathbf{P u}^{6} \mathbf{u}$ 7520 - Spatter and tephra cone at 7,520-ft elev on NERZ. Surrounded by A.D. 1984 flow. Contains 1-2\% scattered, light-green, clear olivine phenocrysts, as much as $8 \mathrm{~mm}$ across. Groundmass is light gray and finely crystalline. FID 897

Pu'ukīpū flow_Poorly exposed, widely scattered 'a'ā kīpuka within other flows and spatter cone Pu'ukīpū $(6,289-\mathrm{ft}$ elev) in north-central Kulani quadrangle. Flow is fine grained and aphanitic. FID 871

$$
\text { Age Group 6 (5,000-6,000 yr B.P.; Holocene) }
$$

p6e1, s6e1, Pu' Pumaka'ala picrite flow_Picritic pāhoehoe and 'a'ā in Puu Makaala, Mountain View, and Hilo a6e1 quadrangles covers 72 sq km. Underlies Kurtistown and Kea'au. Dark groundmass, bluish to 
p6b2, s6b2

p6i3

a6k4

m6h5, a6h5

a6a6

p6i7, a6i7

a6j8

a6a9

s8a2

s8c3

$a 8 b 4$

p8e1

greenish gray, and fine grained. Contains 10-30\% large, clear, yellow-green, subhedral olivine and $0-2 \%$ plagioclase phenocrysts. Xenoliths of gabbro and dunite as much as $1.5 \mathrm{~cm}$ across are common. Where flow is weathered, olivine phenocrysts protrude above rock surface. Characteristically covered with deep layers of soil and ash containing angular rock fragments. Also includes former Puna sugarcane fields. Age, 5,455 25 radiocarbon yr B.P. FID 947

Mountain View flow-Pāhoehoe with wide range of olivine content in Puu Makaala and Mountain View quadrangles. Fresh rock is very dense and dark gray. Contains 3-5\% anhedral olivine phenocrysts. Source vent is one of six that defines lowest exposed extent of NERZ. Flow is covered with average thickness of $60 \mathrm{~cm}$ of orange ash; rock fractures are stained orange. Age, $5,534 \pm 70$ radiocarbon yr B.P. FID 976

Flow 998-Small pāhoehoe kīpuka in central Puu Ulaula quadrangle north of NERZ. Surrounded by Pu 'ukupanaha flow (m1k2, FID 796). Contains 3\% plagioclase microlites and phenocrysts and 1-2\% olivine phenocrysts and microphenocrysts. Groundmass is well crystallized, feldspathic, and light gray. FID 998

Waikahe Road flow-'A 'ā flow with 7\% plagioclase and 3\% olivine phenocrysts and microphenocrysts. Found in Hilo, Piihonua, and Kulani quadrangles. FID 951

Waikoloa Ponds flow—Mixed pāhoehoe and 'a'ā flow, commonly in transitional state, in contact with rocks erupted from Mauna Kea in northwest corner of Upper Piihonua and northeast corner of Puu Oo quadrangles. Contains fine-grained, light-gray groundmass with $<1 \%$, sugary, fine olivine phenocrysts and 8-12\% fine plagioclase phenocrysts. FID 982

Flow 961-Aphanitic 'a'ā unit preserved between lobes of A.D. 1984 flow in Upper Piihonua quadrangle and at distal end of A.D. 1852 flow in Piihonua quadrangle. Flow is dense, with lightgray, slightly feldspathic groundmass. Covered with $\sim 25 \mathrm{~cm}$ of yellow-brown ash probably from Mauna Kea. FID 961

Flow 970 - Vesicular tube-fed pāhoehoe abutting Kūlani Cone and south of Keawewai Camp, in southwest corner of Kulani quadrangle. Flow has 1-3\% each of olivine and plagioclase phenocrysts. Vesicles are subrounded and magnesioferrite lined. Supports thick stands of pūkiawe, mesic forest that makes hiking difficult. Flow near Kūlani Cone covered by slope wash (ash and tephra) from the cone (colluvium). FID 970

'Ōla'a Plantation flow-'A'à with 4-8\% olivine phenocrysts. Contains minor pāhoehoe. Underlies Pu'umaka'ala picrite flow (a6e1, FID 947) near its distal end. In addition to olivine, flow has $3 \%$ plagioclase and rare microgabbroic clots $(<1 \mathrm{~cm})$. FID 955

Pu'umaka'ala Natural Area Reserve flow-Nearly aphyric 'a'ā in Kulani and Puu Makaala quadrangles south of Pana'ewa picrite flow (p2l2, FID 828). Dense, medium- to dark-gray groundmass. Contains $<1 \%$ phenocrysts of olivine. Covered by soil 0-25 cm thick. FID 971

Age Group 7 (6,000-7,000 yr B.P.; Holocene)

[No units of this age group are found at the surface in the map area]

Age Group 8 (7,000-8,000 yr B.P.; Holocene)

Palakea Flat flow_-Picritic pāhoehoe west of Pu'ulala'au in southern Kulani and Puu Makaala quadrangles. Characterized by $25-30 \%$ clear, large, subhedral to anhedral olivine and 0-2\% plagioclase phenocrysts, mostly intergrown with olivine. Vesicles are highly irregular in distribution, subrounded, and commonly magnesioferrite lined. Flow is commonly covered with as much as $2 \mathrm{~m}$ of tan ash; outcrops are fairly common. Dzurisin and others (1995) map distal extent of Uwekahuna Ash member of Puna Basalt to this unit, a distance of $9 \mathrm{~km}$ from Kìlauea.

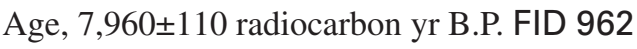

$\mathbf{P u}^{6} \mathbf{u}$ 5400-Cone of deeply weathered aphanitic spatter, $1.6 \mathrm{~km}$ west of Pana'ewa picrite cone (s212, FID 828). Surrounded by Kūlani picrite flow (a1j6, FID 793) in Kulani quadrangle. FID 964

Pu'u 6920 and Pu'u 6480 - Two small outcrops (kīpuka) of deeply weathered spatter west and southwest of Solomons Waterhole and associated flow on west boundary of Kulani quadrangle. Both spatter outcrops are in contact with Upper Waiākea flow (a2k4, FID 864) near its uprift margin. Characterized by 5-10\% olivine phenocrysts. Covered with deep layer of orange-red soil from younger ashfall event of unknown age. FID 965

Flow 994-'A'ā flows in Kulani quadrangle between Kūlani picrite (a1j6, FID 793) and Keawewai Camp flow (a1j12, FID 797) flows. Dense, with no surface glass. Contains 2-3\% scattered 
p8k5, a8k5

a8i6, p8i6, s8i6

p8a7

m8k8, a8k8, p8k8

p8b9

p8e10

s8a11

s8a12

p9l1

p9g2, s9g2, a9g2, m9g2

a9j3

s9a4

a9a5 olivine phenocrysts and abundant, conspicuous, narrow microlaths of plagioclase. Covered by red ash $>1 \mathrm{~m}$ thick that supports a koa forest. FID 994

Flow 983-Tube-fed pāhoehoe in contact with A.D. 1880-81 flow along relay-station road in northeast Puu Ulaula quadrangle. Flow surface severely broken and weathered, retaining very little surface glass and stained orange. Minor olivine phenocrysts form 1-2\% of rock and are mostly intergrown with plagioclase. Abundant, large plagioclase makes up 6-10\% of rock. Rich soil/ash horizons support 'ōhi'a trees as tall as $4 \mathrm{~m}$. FID 983

Flow 979-'A 'ā and minor amounts of tube-fed pāhoehoe in southeast corner of Puu Ulaula quadrangle. Flow contains $1-2 \%$ of clear, inconspicuous olivine and $0-2 \%$ very fine plagioclase phenocrysts. Few fresh surfaces. Overlain by pockets of yellow-brown ash as thick as $25 \mathrm{~cm}$. Deep orange rind where not mechanically weathered. FID 979

Flow 945-Aphanitic tube-fed pāhoehoe near boundary between Puu Ulaula and Puu Oo quadrangles. Unit is between lobes of A.D. 1899 flow. FID 945

Flow 872-Plagioclase-rich 'a'ā and pāhoehoe along north border of Kulani quadrangle and into Upper Piihonua quadrangle; another kīpuka on west boundary of Puu Makaala quadrangle. Contains medium, dark-gray groundmass, round vesicles, $0.5-2 \%$ olivine intergrown with plagioclase, and 10-20\% plagioclase in anhedral and subhedral phenocrysts. Pāhoehoe surface is commonly weathered away to reveal a large vesicle zone below the skin; ' $a$ ' $\bar{a}$ is weathered to completely rounded blocks. FID 872

Flow 975-Tube-fed pāhoehoe in central Upper Piihonua quadrangle. In contact with south margin of A.D. 1855-56 flow. Contains well-crystallized, nearly feldspathic groundmass with $2 \%$ anhedral olivine phenocrysts and abundant plagioclase microphenocrysts. Vesicles are subrounded to spherical, irregularly distributed, and magnesioferrite lined. FID 975

Flow 963-Scattered pāhoehoe flows north and west of Kūlani Cone Complex. Deeply weathered, with dense, dark-gray groundmass and elongate vesicles. Contains large, euhedral olivine phenocrysts forming $10-20 \%$ of rock. Overlain by as much as $1 \mathrm{~m}$ of yellow ash. Standing water and 'ōhi'a dieback found at some sites. FID 963

Upper 'Ōla'a flow-Spatter cone in contact with 'Ōla'a Uka flow (a1l15; FID 795) east of Kūlani Cone Complex (s11k6, FID 980). Younger tephra and ash overlie this cone's spatter deposits. 'Ōhi'a dieback at some locations. FID 969

Flow 968-Small outcrop west of Pu'ulala'au (s11j8; FID 967) in Kulani quadrangle. Approximately $80 \mathrm{~cm}$ of yellow-orange ash overlies aphyric spatter composed of black clasts with sparse plagioclase microphenocrysts. FID 968

$$
\text { Age Group } 9 \text { (8,000-9,000 yr B.P.; Holocene) }
$$

Alawaena Road flow-Pāhoehoe flow in Piihonua and Hilo quadrangles. Contains 8\% clear subhedral olivine phenocrysts and 10-12\% subhedral plagioclase phenocrysts, commonly intergrown with olivine. Flow is deeply weathered and stained. Poorly exposed outcrops underlie $20-30 \mathrm{~cm}$ of ash. Age, 8,030 70 radiocarbon yr B.P. FID 952

Pu'u'ula'ula flow-Pāhoehoe, minor 'a'ā, and spatter from Pu' 'u'ula'ula, one of largest cones on NERZ. A distinct unit, containing 3-4\% fine plagioclase phenocrysts. Black and scoriaceous where fresh, otherwise oxidized to red brown. Flow groundmass is light gray and orange stained, with many inconspicuous needles of plagioclase. Flow is commonly covered with as much as $1 \mathrm{~m}$ of tan ash especially at lower elevations; outcrops are fairly common. Age, $8,645 \pm 71$ radiocarbon yr B.P. FID 978

Kino'ole Street flow-'A‘ā on northwest side of Waiākea Stream bank above Kino'ole Street Bridge in Hilo. Flow has dense flinty groundmass with small, sparse, angular vesicles. Contains $2-8 \%$ subhedral olivine phenocrysts and $2-5 \%$ fine, anhedral plagioclase phenocrysts and microphenocrysts, generally intergrown with olivine. Overlies 'Āinaola Drive picrite flow (a10e1, FID 953); contact is marked by clasts of picritic 'a'a and brown soil. Age, 8,673 \pm 55 radiocarbon yr B.P. FID 948

$\mathbf{P u}^{6} \mathbf{u}$ 6480 - Deeply weathered aphanitic spatter at vent in southwest corner of Kulani quadrangle at 6,480-ft elev. Sandwiched between Keauhou Ranch flow (p1l13, FID 833) on northeast and Ke‘āmoku Kīpukakēkake flow (a1g1, FID 800) on southwest. FID 966

Flow 956-Small aphanitic 'a'ā outcrop surrounded by Pana'ewa picrite (a2I2, FID 828) flow south of the Pana'ewa Zoo. FID 956 
p10e1, a10e1， 'Āinaola Drive picrite flow—Picritic pāhoehoe and 'a 'ā underlying most of south Hilo and s10e1 University of Hawai 'i campus. Found in Kulani, Puu Makaala, Piihonua, and Hilo quadrangles. Characterized by 15-20\% large, clear, yellow-green olivine phenocrysts and 0-2\% plagioclase phenocrysts. Flow consists of massive 'a' $\bar{a}$, commonly $>5 \mathrm{~m}$ thick. Interior of flow typically contains large, round, magnesioferrite-lined vesicles; pipe vesicles at base of flow. Age, $9,020 \pm 88$ radiocarbon yr B.P. FID 953

p10b2 Waiākea Homesteads flow-Deeply weathered, tube-fed pāhoehoe flow in Piihonua, Puu Makaala, and Hilo quadrangles. Contains slightly feldspathic groundmass. Vesicles are spherical, uniformly sized, and magnesioferrite lined. Ranges from aphanitic to slightly porphyritic, with scattered olivine phenocrysts (2\%) and abundant plagioclase microphenocrysts. Age, 9,672 \pm 40 radiocarbon yr B.P. FID 957

s10l3 Pu'u 3500 — Cone and associated flow on Stainback Highway at 3,400-ft elev in Puu Makaala quadrangle. Contains 5-7\% olivine phenocrysts and 4-7\% plagioclase. One of a few vents, of differing ages, that help define lower limits of NERZ. FID 946

Age Group 11 (10,000-15,000 yr B.P.; Holocene and Pleistocene)

a11d1, p11d1 Waikoloa Ponds of Wailuku flow_Pāhoehoe and 'a'ā along Wailuku River in Upper Piihonua quadrangle. Contains 10-15\% inconspicuous olivine phenocrysts and microphenocrysts. Age, 10,161 29 radiocarbon yr B.P. FID 981

$\mathrm{p} 11 \mathrm{j} 2$

a11c3

Flow north of Pu'ulala'au - Pāhoehoe in contact with north side of Pu'ulala'au in Kulani quadrangle. Contains 5-10\% fine, light-green olivine phenocrysts and 1-2\% fine anhedral plagioclase. Covered with average of $0.5 \mathrm{~m}$ of yellow-orange ash. Age, 10,400 \pm 150 radiocarbon yr B.P. FID 974

'Ānuenue flow-Dense, olivine-rich 'a 'ā in Upper Piihonua, Piihonua, and Hilo quadrangles. Forms most of Wailuku River bed in Upper Piihonua and Piihonua quadrangles at Boiling Pots. Contains medium-gray, flinty, well-crystallized, fine-grained groundmass containing 5-12\% large, clear, subhedral olivine phenocrysts. Steep flow foliations are visible in valley- and stream-plastering flows and levees south of Wailuku River. Commonly overlain by $2-3 \mathrm{~m}$ of deeply sculpted ash from Mauna Kea. Age, 10,405 \pm 37 radiocarbon yr B.P. FID 950

p11f4, a11f4 Mauna Hu'ihu'i flow_Vesicular picritic pāhoehoe and 'a'ā in southeastern Puu Makaala and southwestern Mountain View quadrangles. Flow is vesicular, generally oxidized to orangeyellow color, with dark-blue-gray groundmass where fresh. Contains 5-30\% altered, lightgreen, equant olivine phenocrysts and $0-2 \%$ plagioclase laths. In some areas, olivine crystals are so abundant that they are easily removed from rock when rubbed. Pāhoehoe unit contains a very large ( $>7 \mathrm{~m}$ diam) tube system. Commonly overlain by $2.5 \mathrm{~m}$ of ash. Age, 10,660 \pm 400 radiocarbon yr B.P. FID 985

p11a5

Waiānuenue flow-Aphanitic tube-fed pāhoehoe flow in Piihonua and Hilo quadrangles. Forms streambed of Kahoama Stream and base of several plunge pools in Wailuku River. Contains near-flinty groundmass and small, spherical, uniformly sized vesicles. Ranges from 3 to $5 \mathrm{~m}$ thick and consists of several flow units. Enters ocean on south bank of Wailuku River near sewage outfall. Forms prominent outcrop at mouth of river called Māui's Canoe. Where preserved, unit is overlain by yellow-brown ash as thick as $2-3 \mathrm{~m}$. Age, 14,173 \pm 37 radiocarbon yr B.P. FID 949

s11k6

Kūlani Cone Complex - Spatter and lava bombs from largest cone complex on NERZ. Spatter contains $8-10 \%$ subhedral plagioclase laths and $1-3 \%$ olivine phenocrysts. Buried by $>2 \mathrm{~m}$ of ash. Source is fissure vent $300 \mathrm{~m}$ northeast of base of cone. High fountaining created off-center cone complex, which formed by downwind accumulation of tephra. Another small cone $7 \mathrm{~km}$ downrift has similar mineralogy and age characteristic and, therefore, is combined with this unit. FID 980

a11e7 Laulā Road flow—Dense 'a'ā olivine picrite in Waiākea area of Hilo. Contains fine-grained, dark-gray groundmass and randomly distributed, spherical vesicles. Clear, green, subhedral olivine phenocrysts form $25-35 \%$ of rock. Numerous, round, olivine-plagioclase xenoliths $(0.5-1.5 \mathrm{~cm})$ are found locally. Deeply weathered yellow surfaces are almost completely decomposed at some sites. FID 958 
Pu'ulala'au cone-Spatter rampart at $\mathrm{Pu}$ 'ulala'au covered with $\sim 0.5 \mathrm{~m}$ of yellow ash containing lithic fragments as much as $2 \mathrm{~cm}$ diam (Uwekahuna Ash Member of Puna Basalt). Variable olivine mineralogy contains $1-10 \%$ phenocrysts and microphenocrysts and $4-5 \%$ plagioclase phenocrysts. Overlain by unit p11j2 (FID 974). FID 967

p11h9 Flow 984-Small areas of tube-fed pāhoehoe surrounded by Kīlauea flows dated at 750-400 yr B.P. (Wolfe and Morris, 1996) in Mountain View quadrangle, $\sim 4 \mathrm{~km}$ southeast of Kea 'au. Contains $8 \%$ plagioclase phenocrysts. Characterized by light-gray, well-crystallized groundmass and round, orange-stained vesicles. FID 984

Age Group 12 (15,000-20,000 yr B.P.; Pleistocene)

s12e1 Hāla'i Hills flows-Formerly three tephra cones that trend northeast at crest of Hilo. Two were almost entirely lost to cinder quarrying. Contains $15-25 \%$ large, green, clear olivine phenocrysts. Eruptive products include spatter, rootless flows, and local pāhoehoe. FID 997

Age Group 13 (20,000-30,000 yr B.P.; Pleistocene)

p13a1 Kaluiiki flow-Aphanitic pāhoehoe of eastern Piihonua quadrangle is covered by as much as $2 \mathrm{~m}$ of ash (tn) in map area. Age, 28,145 \pm 333 radiocarbon yr B.P. FID 960

\section{Kahuku Basalt}

The Kahuku Basalt consists of units with an age range of 30,000 to 100,000 years. The Kahuku Basalt comprises tholeiitic basalt, tuffs, vent deposits, and lava flows that rest unconformably on the Ninole Basalt. The flows are mostly aphyric and some have variable amounts of olivine and plagioclase phenocrysts. The Kahuku Basalt type locality is the Kahuku Pali or Kahuku Fault near South Point (Kalae). Kahuku Basalt rocks are also exposed in scarps north of Wai 'ōhinu and at the coast from Waikapuna to Honu'apo, at Māniania Pali.

Age Group 14 (30,000-100,000 yr B.P.; Pleistocene)

[No units of this age group are found at the surface in the map area]

Ninole Basalt

The Ninole Basalt includes the oldest exposed rocks on Mauna Loa at greater than 100,000 yr B.P. These rocks are exposed in the Ka' $\bar{u}$ District. The Ninole Basalt consists of tholeiitic basalt, tuffs, vent deposits, and lava flows. The flows are mostly aphyric and some have variable amounts of olivine and plagioclase phenocrysts.

Age Group 15 (>100,000 yr B.P.; Pleistocene)

[No units of this age group are found at the surface in the map area]

\section{DISTAL TEPHRA DEPOSITS}

tn

ts
Tephra (Holocene and Pleistocene)

Northern tephra-Beds of fallout and surge deposits in northern map area are chiefly from Mauna Kea with minor contributions from Kīlauea and possibly Mauna Loa. Hilo area deposits were mapped previously as Homelani ash deposits (Buchanan-Banks, 1993). FID 996

Southern tephra-Beds of fallout and surge deposits near Kūlani Cone and in southern map area are chiefly from Kīlauea Volcano and likely include contributions from Mauna Loa and Mauna Kea. Kīlauea deposits include ${ }^{14} \mathrm{C}$ ages of 2,110 $\pm 120 \mathrm{yr}$ B.P., 2,265 $\pm 50 \mathrm{yr}$ B.P., and 2,770 $\pm 70 \mathrm{yr}$ B.P., all dating Uwekahuna Ash Member of Puna Basalt (Dzurisin and others, 1995). Another age of 4,135 \pm 49 was obtained from tephra on the east flank of the volcano. Distributions of ash near Killauea seem to be influenced by the inversion layer on windward coast of Island of Hawai' $i$, which seems to extend as high as $26,240-29,520 \mathrm{ft}$. This meteoric phenomenon appears to limit distribution of ash to lower elevations; therefore, overlay patterns for tephra deposits may vary with elevation within flows or on flows of similar age. Possibly, tephra deposited at higher elevations (alpine and above) lack vegetative cover that preserves it, allowing combined wind and rainfall to strip deposits from higher elevations. FID 959 


\section{References Cited}

Buchanan-Banks, J.M., 1983, Map showing thicknesses of volcanic ash deposits, greater Hilo area, Hawaii: U.S. Geological Survey Miscellaneous Field Studies Map MF-1499, scale 1:24,000.

Buchanan-Banks, J.M., 1993, Geologic map of Hilo 7 1/2' quadrangle, Island of Hawaii: U.S. Geological Survey Miscellaneous Investigations Series Map I-2274, scale 1:24,000, $17 \mathrm{p}$.

Buchanan-Banks, J.M., Lockwood, J.P., and Rubin, Meyer, 1989, Radiocarbon dates for lava flows from northeast rift zone of Mauna Loa volcano, Hilo 7 1/2' quadrangle, Island of Hawaii: Radiocarbon, v. 31, p. 179-186.

Dzurisin, D., Lockwood, J.P., Casadevall, T.J., and Rubin, Meyer, 1995, The Uwekahuna Ash Member of the Puna Basalt-Product of violent phreatomagmatic eruptions at Kilauea Volcano, Hawaii, between 2,800 and 2,100 ${ }^{14} \mathrm{C}$ years ago: Journal of Volcanology and Geothermal Research, v. 66, p. 163-184.

Easton, M., 1987, Stratigraphy of Kilauea Volcano, in Decker, R.W., Wright, T.L., and Stauffer, P.H., eds., Volcanism in Hawaii: U.S. Geological Survey Professional Paper 1350, v. 1 , chap. 11 , p. 243-260.

Finch, R.H., and Macdonald, G.A., 1953, Hawaiian volcanoes during 1950: U.S. Geological Survey Bulletin 996-B, p. 27-89.

Fraser, G.D., 1960, Pahala ash-An unusual deposit from Kilauea Volcano, Hawaii: U.S. Geological Survey Professional Paper 400-B, p. 354-355.

Kelley, M.L., 1979, Radiocarbon dates from the Hawaiian Islands-A compilation: U.S. Geological Survey OpenFile Report 79-1700, 37 p.

Kelley, M.L., Spiker, E.C., Lipman, P.W., and 3 others, 1979, U.S. Geological Survey, Reston, Virginia, radiocarbon dates XV-Mauna Loa and Kilauea volcanoes, Hawaii: Radiocarbon, v. 21, no. 2, p. 306-320.

Lipman, P.W., 1980, Rates of volcanic activity along the southwest rift zone of Mauna Loa Volcano, Hawaii: Bulletin Volcanologique, v. 43, p. 703-725.

Lockwood, J.P., 1984, Geologic map of Mauna Loa Volcano, Hawaii-Kulani quadrangle: U.S. Geological Survey Open-File Report 84-12, scale 1:24,000.

Lockwood, J.P., 1990, Implications of historical eruptive-vent migration on the northeast rift zone of Mauna Loa volcano, Hawaii: Geology, v. 15, p. 611-613.

Lockwood, J.P., 1995, Mauna Loa eruptive history-The preliminary radiocarbon record, in Rhodes, J.M., and Lockwood, J.P., eds., Mauna Loa revealed-Structure, composition, history, and hazards: American Geophysical Union Geophysical Monograph, 92, p. 81-94.

Lockwood, J.P., and Lipman, P.W., 1980, Recovery of datable charcoal from beneath young lava flows-Lessons from Hawaii: Bulletin Volcanologique, v. 43, p. 609-615.

Lockwood, J.P., and Lipman, P.W., 1987, Holocene eruptive history of Mauna Loa volcano, in Decker, R.W., Wright, T.L., and Stauffer, P.H., eds., Volcanism in Hawaii: U.S. Geo- logical Survey Professional Paper 1350, v. 1, p. 509-536.

Lockwood, J.P., Lipman, P.W, Petersen, L.D., and Warshauer, F.R., 1988, Generalized ages of surface flows of Mauna Loa volcano, Hawaii: U.S. Geological Survey Miscellaneous Investigations Series Map I-1908, scale 1:250,000.

Reimer, P.J., Baillie, M.G.L., Bard, E., and 25 others, 2009, IntCal09 and Marine09 radiocarbon age calibration curves, 0-50,000 years cal B.P.: Radiocarbon, v. 51, no. 4, p. 1111-1150.

Rubin, Meyer, Gargulinski, L.K., and McGeehin, J.P., 1987, Hawaiian radiocarbon dates, in Decker, R.W, Wright, T.L., and Stauffer, P.H., eds., Volcanism in Hawaii: U.S. Geological Survey Professional Paper 1350, v. 1, p. 213-242.

Stearns, H.T., and Clark, W.O., 1930, Geology and water resources of the Kau District, Hawaii: U.S. Geological Survey Water-Supply Paper 616, 194 p.

Stearns, H.T., and Macdonald, G.A., 1946, Geology and groundwater resources of the island of Hawaii: Hawaii Division of Hydrography, Bulletin 9, 363 p.

Stone, J.B., 1926, The products and structure of Kilauea: Bernice P. Bishop Museum, Bulletin 33, 59 p., includes plates.

Stuiver, M., Reimer, P.J., Bard, E., and 7 others, 1998, INTCAL98 radiocarbon age calibration 0-24,000 B.P.: Radiocarbon, v. 40, no. 3, p. 1041-1083.

Stuiver, M., Reimer, P.J., and Reimer, R.W. 2005, CALIB Radiocarbon Calibration: Marine Reservoir Correction Database (program and documentation), v. 6.0, http://calibqub.ac.ik/calib/.

Taylor, J.R., 1982, An introduction to error analysis: Mill Valley, Calif., University Science Books, 270 p.

Trusdell, F.A., 1995, Lava flow hazards and risk assessment on Mauna Loa Volcano, Hawaii, in Rhodes, J.M., and Lockwood, J.P., eds., Mauna Loa revealed-Structure, composition, history, and hazards: American Geophysical Union, Monograph 92, p. 327-336.

Walker, G.W., 1969, Geologic map of the Kau Desert quadrangle, Hawaii: U.S. Geological Survey Geologic Quadrangle Map GQ-827.

Wentworth, C.K., 1938, Ash formation of the Island of Hawaii: Honolulu, Hawaiian Volcano Observatory of Hawaii National Park and Hawaiian Volcano Research Association, 3rd special report, $183 \mathrm{p}$.

Wolfe, E.W., and Morris, Jean, 1996, Geologic map of the Island of Hawaii: U.S. Geological Survey Miscellaneous Investigations Series Map I-2524-A, scale 1:100,000.

\section{Hawaiian Language References}

Pukui, M.K., Elbert, S.H., and Mookini, E.T., 1974, Place names of Hawaii: Honolulu, University of Hawaii Press, 289 p.

United States Board on Geographic Names, 2016, Geographic_ names database: U.S. Geological Survey, accessed February 5, 2016, at http://geonames.usgs.gov/domestic/index.html.

University of Hawaii Geography Department, 1974, Atlas of Hawaii: Honolulu, University of Hawaii Press, 250 p. 


\section{Appendix}

This appendix contains radiocarbon ages that were rejected and not used in the study of the northeast flank of Mauna Loa, Island of Hawai 'i, Hawaii. Reasons for rejection include age too old or too young, and age not consistent with stratigraphy, suggesting contamination.

\begin{tabular}{|c|c|c|c|c|c|c|c|}
\hline FID $^{1}$ & Field No. & Lab No. & $\begin{array}{c}\text { Quadrangle name } \\
(1: 24,000)\end{array}$ & $\begin{array}{c}\text { Age }^{2} \\
\text { (yr B.P.) }\end{array}$ & $\begin{array}{l}\text { S.D. }{ }^{2} \\
(\mathbf{y r})\end{array}$ & $\begin{array}{l}\text { Reason for } \\
\text { rejection }^{3}\end{array}$ & $\begin{array}{c}\text { Data } \\
\text { source }\end{array}$ \\
\hline 795 & KUd-160 & W4813 & Kulani & 1,380 & 60 & A & 2 \\
\hline 799 & KUc-103 & W4341 & Kulani & 330 & 60 & A & 2 \\
\hline 799 & L-77-42A & W3879 & Kilauea Crater & 830 & 60 & A & 2 \\
\hline 799 & KUc-130 & W4870 & Kulani & 1,100 & 70 & $\mathrm{~A}$ & 1,2 \\
\hline 801 & 77L-09 & W3836 & Kilauea Crater & 2,830 & 60 & B & 1,2 \\
\hline 801 & L-80-126 & W4801 & Kilauea Crater & 730 & 70 & B & 1,2 \\
\hline 828 & L-78-13 & W4174 & Hilo & 2,890 & 70 & $\mathrm{~A}$ & 1,2 \\
\hline 829 & KUc-130 & W4882 & Kulani & 430 & 70 & B & 2,3 \\
\hline 838 & L-78-01 & W4049 & Kipuka Pakekake & 420 & 70 & B & 2 \\
\hline 838 & PUd-135 & W4571 & Puu Ulaula & 440 & 70 & $\mathrm{~B}$ & 2 \\
\hline 863 & KUa-154 & W4985 & Kulani & 1,760 & 60 & A & 2 \\
\hline 863 & L-91-183 & WW845 & Upper Piihonua & 4,520 & 50 & $\mathrm{~A}$ & 2 \\
\hline 874 & KUc-125 & W4807 & Kulani & 620 & 70 & B & 2 \\
\hline
\end{tabular}

${ }^{1}$ Unique three-digit flow identification number (FID) assigned to each mapped surface flow, vent, and ash unit is necessary to utilize database (https://doi.org/10.3133/sim2932A).

${ }^{2}$ Each age was calibrated to calendar years using CALIB 4.0 Radiocarbon Calibration Program (Stuiver and others, 1998); calibrated ages are for two standard deviations (S.D.). Samples were processed at U.S. Geological Survey, ${ }^{14} \mathrm{C}$ laboratory, Reston, Va.

${ }^{3} \mathrm{~A}$, age too old based on stratigraphic constraints, possibly contaminated; B, age too young based on stratigraphic constraints, possibly contaminated.

${ }^{4}$ Sources: 1, Kelley and others (1979); 2, Rubin and others (1987); 3, Buchanan-Banks and others (1989). 
Table 2. Radiocarbon ages of samples from the northeast flank of Mauna Loa, Island of Hawai'i, Hawaii.

[All ages are reported as radiocarbon years before present (yr B.P., before the calendar year datum of A.D. 1950); meaningless (large analytical error) or incorrect (using all age data and regional stratigraphic relations) ages are reported in the Appendix. Dated materials include charcoal, roots, twigs, vegetative litter, or unaltered wood (rarely). A variance is reported as one standard deviation, in years. See figure 1 for quadrangle locations. Note quadrangles were published 1980-82]

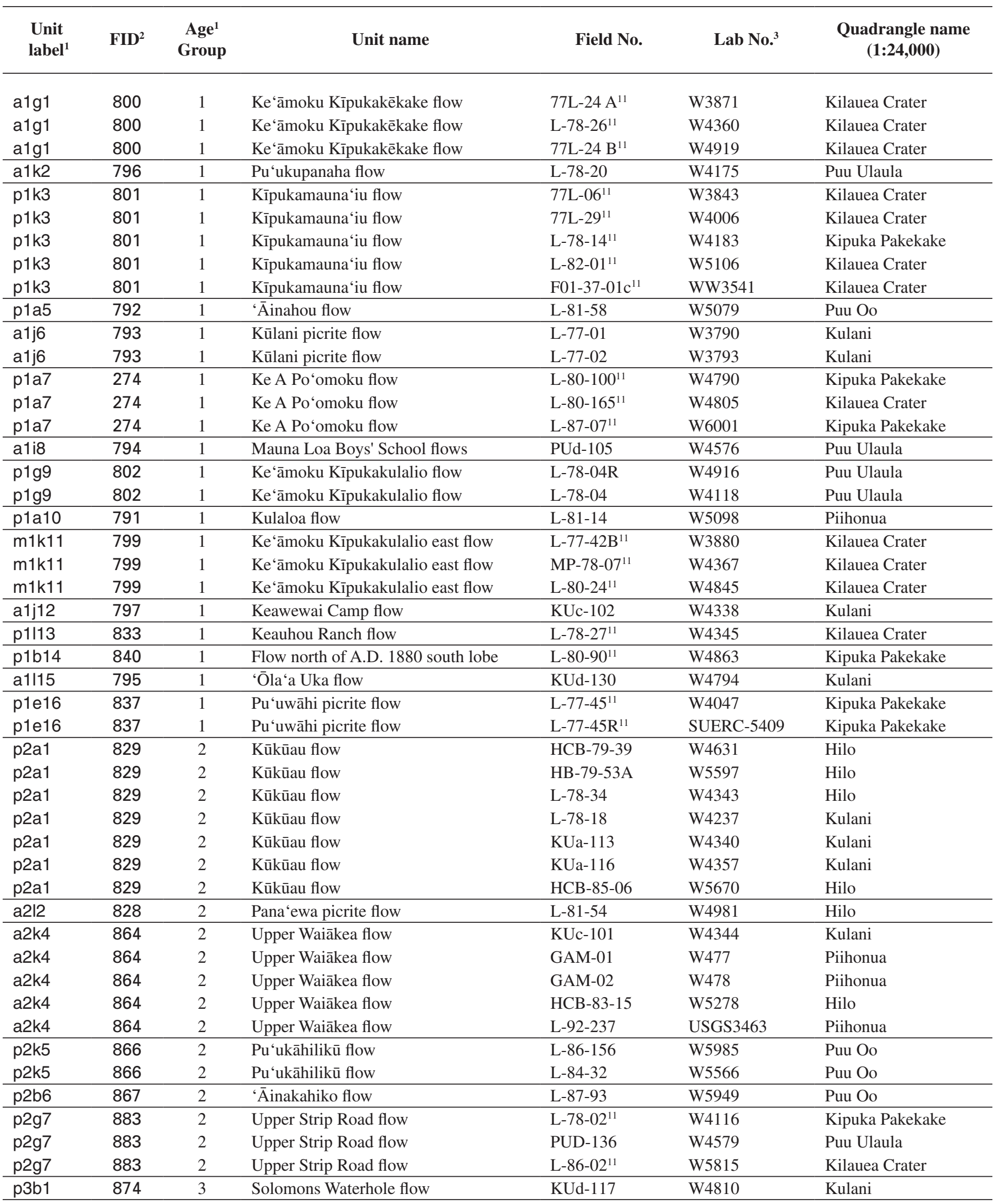




\begin{tabular}{|c|c|c|c|c|c|c|c|c|c|}
\hline $\begin{array}{l}\text { Latitude }^{4} \\
\text { (degree) }\end{array}$ & $\begin{array}{c}\text { Longitude }^{4} \\
\text { (degree) }\end{array}$ & $\begin{array}{l}\text { Elevation } \\
\text { (ft) }\end{array}$ & $\begin{array}{c}\text { Age }^{5} \\
(y \mathbf{r} \\
\text { B.P. }) \\
\end{array}$ & $\begin{array}{l}\text { S.D. } \\
(y \mathbf{r})\end{array}$ & $\begin{array}{l}\text { Weighted } \\
\text { average }^{6} \\
\text { (yr B.P.) }\end{array}$ & $\begin{array}{l}\text { S.D. } \\
(y r)\end{array}$ & Quality $^{7}$ & $\begin{array}{c}\text { Age range }^{8} \\
\text { (calendar } \\
\text { years) }\end{array}$ & Source $^{9}$ \\
\hline 19.44550 & -155.31870 & 4,200 & 230 & 60 & 288 & 36 & + & 1491 to 1953 & 1,2 \\
\hline 19.49374 & -155.34480 & 5,500 & 300 & 60 & 288 & 36 & + & 1448 to 1951 & 2 \\
\hline 19.44556 & -155.31861 & 4,203 & 350 & 70 & 288 & 36 & 0 & 1433 to 1790 & 2 \\
\hline 19.58656 & -155.42234 & 7,520 & 300 & 50 & & & + & 1462 to 1795 & 1,2 \\
\hline 19.40900 & -155.34350 & 3,500 & 290 & 50 & 311 & 25 & & 1460 to 1950 & 1,2 \\
\hline 19.41211 & -155.34209 & 3,590 & 290 & 70 & 311 & 25 & + & 1447 to 1951 & 1,2 \\
\hline 19.49547 & -155.44440 & 8,360 & 300 & 60 & 311 & 25 & + & 1448 to 1951 & 1,2 \\
\hline 19.41648 & -155.34947 & 3,825 & 300 & 80 & 311 & 25 & + & 1437 to 1952 & 2 \\
\hline 19.41100 & -155.34185 & 3,570 & 340 & 40 & 311 & 25 & + & 1462 to 1642 & 3 \\
\hline 19.66047 & -155.46599 & 6,755 & 410 & 60 & & & + & 1419 to 1635 & 2 \\
\hline 19.55343 & -155.30112 & 5,165 & 420 & 70 & 437 & 46 & + & 1402 to 1642 & 1,2 \\
\hline 19.55197 & -155.30115 & 5,165 & 450 & 60 & 437 & 46 & + & 1334 to 1627 & 1,2 \\
\hline 19.44033 & -155.40200 & 5,280 & 540 & 70 & 475 & 41 & + & 1285 to 1464 & 2 \\
\hline 19.39717 & -155.37120 & 3,790 & 340 & 60 & 475 & 41 & 0 & 1445 to 1653 & 2 \\
\hline 19.40033 & -155.38550 & 4,350 & 720 & 100 & 475 & 41 & 0 & 1048 to 1422 & 3 \\
\hline 19.55400 & -155.40606 & 7,920 & 480 & 60 & & & + & 1306 to 1624 & 2 \\
\hline 19.50320 & -155.38600 & 6,815 & 560 & 70 & 569 & 53 & + & 1287 to 1446 & 3 \\
\hline 19.50320 & -155.38600 & 6,815 & 580 & 80 & 569 & 53 & + & 1274 to 1449 & 1,2 \\
\hline 19.62689 & -155.14057 & 1,520 & 570 & 60 & & & + & 1293 to 1436 & 2,4 \\
\hline 19.46330 & -155.28450 & 4,100 & 530 & 60 & 575 & 38 & + & 1296 to 1453 & 1,2 \\
\hline 19.44250 & -155.27470 & 4,060 & 570 & 70 & 575 & 38 & + & 1286 to 1442 & 2 \\
\hline 19.47130 & -155.29582 & 4,425 & 640 & 70 & 575 & 38 & 0 & 1262 to 1424 & 2 \\
\hline 19.52871 & -155.34626 & 6,190 & 590 & 50 & & & + & 1291 to 1422 & 2 \\
\hline 19.49270 & -155.34350 & 5,450 & 760 & 70 & & & + & 1050 to 1392 & 2 \\
\hline 19.46670 & -155.41900 & 7,395 & 780 & 70 & & & + & 1045 to 1387 & 2 \\
\hline 19.51961 & -155.30145 & 5,030 & 880 & 60 & & & + & 1032 to 1256 & 2 \\
\hline 19.48713 & -155.38640 & 6,350 & 910 & 70 & 955 & 24 & + & 1016 to 1259 & 1,2 \\
\hline 19.48713 & -155.38640 & 6,350 & 961 & 25 & 955 & 24 & + & 1020 to 1155 & 3 \\
\hline 19.70639 & -155.08611 & 135 & 1,110 & 60 & 1,333 & 26 & + & 778 to 1022 & 4 \\
\hline 19.71575 & -155.09520 & 150 & 1,140 & 300 & 1,333 & 26 & 0 & 260 to 1409 & $2,4,5$ \\
\hline 19.66969 & -155.12245 & 760 & 1,280 & 70 & 1,333 & 26 & + & 639 to 936 & $2,4,5$ \\
\hline 19.56323 & -155.34484 & 6,180 & 1,320 & 50 & 1,333 & 26 & + & 618 to 856 & 2 \\
\hline 19.59510 & -155.34744 & 5,835 & 1,400 & 70 & 1,333 & 26 & + & 442 to 776 & 2 \\
\hline 19.58410 & -155.34835 & 5,945 & 1,490 & 50 & 1,333 & 26 & 0 & 433 to 650 & 2 \\
\hline 19.66473 & -155.12236 & 780 & 1,500 & 200 & 1,333 & 26 & 0 & 88 to 968 & 4,5 \\
\hline 19.64286 & -155.05660 & 360 & 1,470 & 50 & & & + & 436 to 659 & $2,4,5$ \\
\hline 19.53253 & -155.35345 & 6,440 & 1,690 & 70 & 1,638 & 32 & + & 143 to 539 & 2 \\
\hline 19.67830 & -155.12170 & 800 & 2,000 & 250 & 1,638 & 32 & 0 & -748 to 558 & 2 \\
\hline 19.67830 & -155.12170 & 800 & 2,070 & 250 & 1,638 & 32 & 0 & -769 to 428 & 2 \\
\hline 19.66867 & -155.60867 & 660 & 1,740 & 100 & 1,638 & 32 & + & 78 to 535 & 2 \\
\hline 19.62000 & -155.14400 & 1,740 & 1,585 & 40 & 1,638 & 32 & + & 398 to 564 & 2 \\
\hline 19.69001 & -155.46750 & 6,600 & 1,580 & 120 & 1,838 & 94 & + & 173 to 668 & 3 \\
\hline 19.70170 & -155.39007 & 5,715 & 2,240 & 150 & 1,838 & 94 & + & -758 to 49 & 2 \\
\hline 19.63938 & -155.46071 & 6,855 & 1,880 & 200 & & & + & -362 to 550 & 3 \\
\hline 19.48600 & -155.38550 & 6,280 & 1,840 & 60 & 1,993 & 43 & + & 32 to 336 & 1 \\
\hline 19.50900 & -155.39580 & 7,260 & 2,120 & 70 & 1,993 & 43 & + & -366 to 16 & 2 \\
\hline 19.45280 & -155.34970 & 4,770 & 2,270 & 130 & 1,993 & 43 & + & -767 to -6 & 2 \\
\hline 19.53479 & -155.28852 & 4,750 & 2,550 & 80 & & & + & -508 to -57 & 2 \\
\hline
\end{tabular}


Table 2. Radiocarbon ages of samples from the northeast flank of Mauna Loa, Island of Hawai'i, Hawaii.—Continued

\begin{tabular}{|c|c|c|c|c|c|c|}
\hline $\begin{array}{l}\text { Unit } \\
\text { label }^{1}\end{array}$ & FID $^{2}$ & $\begin{array}{c}\text { Age }^{1} \\
\text { Group }\end{array}$ & Unit name & Field No. & Lab No. ${ }^{3}$ & $\begin{array}{c}\text { Quadrangle name } \\
(1: 24,000)\end{array}$ \\
\hline p4a1 & 863 & 4 & Punahoa flow & L-82-33 & W5112 & Upper Piihonua \\
\hline p4a1 & 863 & 4 & Punahoa flow & HCB-79-55 & W4629 & Hilo \\
\hline p4a1 & 863 & 4 & Punahoa flow & PCB-09-78 & W4624 & Piihonua \\
\hline p4a1 & 863 & 4 & Punahoa flow & L-92-230E & WW849 & Piihonua \\
\hline p4a1 & 863 & 4 & Punahoa flow & L-79-67 & W4574 & Piihonua \\
\hline $\mathrm{p} 4 \mathrm{f} 2$ & 868 & 4 & Kīpuka 'Āinahou flow & L-84-79 & W5565 & Upper Piihonua \\
\hline $\mathrm{p} 4 \mathrm{f} 2$ & 868 & 4 & Kīpuka 'Āinahou flow & L-84-79R & WW3715 & Upper Piihonua \\
\hline ts & 959 & 5 & Undivided tephra & L-91-624 ${ }^{11}$ & W6477 & Keaiwa Reservoir \\
\hline p5a1 & 954 & 5 & Wilder Road flow & L-81-22R & SUERC-5410 & Piihonua \\
\hline p5a1 & 954 & 5 & Wilder Road flow & L-96-01 & WW880 & Hilo \\
\hline p5a1 & 954 & 5 & Wilder Road flow & HCB-81-45 & W5077 & Hilo \\
\hline a5a2 & 876 & 5 & Waiakeawaena flow & L-81-34 & W4982 & Upper Piihonua \\
\hline a5a2 & 876 & 5 & Waiakeawaena flow & L-84-80 & W5567 & Upper Piihonua \\
\hline p6e1 & 947 & 6 & $\mathrm{Pu}$ 'umaka'ala picrite flow & L-79-37 & W4536 & Mountain View \\
\hline p6e1 & 947 & 6 & $\mathrm{Pu}^{\prime}$ umaka'ala picrite flow & L-79-37R & WW3712 & Mountain View \\
\hline p6e1 & 947 & 6 & Pu'umaka'ala picrite flow & L-88-120A & W6173 & Puumakaala \\
\hline p6e1 & 947 & 6 & Pu'umaka'ala picrite flow & L-98-01 & WW1935 & Mountain View \\
\hline s6b2 & 976 & 6 & Mountain View flow & L-89-01 & W6224 & Mountain View \\
\hline p10e1 & 953 & 10 & 'Āinaola Drive picrite flow & L-81-03 & W4975 & Piihonua \\
\hline p10e1 & 953 & 10 & 'Āinaola Drive picrite flow & L-89-06 & W6226 & Hilo \\
\hline p10b2 & 957 & 10 & Waiākea Homesteads flow & L-92-240 & WW850 & Piihonua \\
\hline p10b2 & 957 & 10 & Waiākea Homesteads flow & L-79-23 & W4529 & Piihonua \\
\hline p10b2 & 957 & 10 & Waiākea Homesteads flow & HCB-80-27A & W4884 & Hilo \\
\hline p10b2 & 957 & 10 & Waiākea Homesteads flow & L-81-01 & W5087 & Piihonua \\
\hline p11d1 & 981 & 11 & Waikoloa Ponds of Wailuku flow & L-81-33 & W5092 & Upper Piihonua \\
\hline $\mathrm{p} 11 \mathrm{~d} 1$ & 981 & 11 & Waikoloa Ponds of Wailuku flow & L-81-33R & WW3713 & Upper Piihonua \\
\hline $\mathrm{p} 11 \mathrm{j} 2$ & 974 & 11 & Flow north of Pu'ulala‘au & KUc-176 & W4995 & Kulani \\
\hline a11c3 & 950 & 11 & 'Ānuenue flow & L-92-46 & USGS3460 & Upper Piihonua \\
\hline a11c3 & 950 & 11 & 'Ānuenue flow & L-81-70 & W5103 & Piihonua \\
\hline a11c3 & 950 & 11 & 'Ānuenue flow & L-92-230B & AA10601 & Piihonua \\
\hline a11c3 & 950 & 11 & ‘Ānuenue flow & HWCB-80-06H & W4623 & Hilo \\
\hline a11c3 & 950 & 11 & 'Ānuenue flow & L-95-04 & WW875 & Hilo \\
\hline $\mathrm{p} 11 \mathrm{f4}$ & 985 & 11 & Mauna $\mathrm{Hu}$ 'ihu'i flow & L-86-234 & W5942 & Puu Makaala \\
\hline p11a5 & 949 & 11 & Waiānuenue flow & HCB-80-37 & W4627 & Hilo \\
\hline p11a5 & 949 & 11 & Waiānuenue flow & HCB-81-19 & W4971 & Hilo \\
\hline p11a5 & 949 & 11 & Waiānuenue flow & L-81-07 & W5091 & Piihonua \\
\hline
\end{tabular}




\begin{tabular}{|c|c|c|c|c|c|c|c|c|c|}
\hline $\begin{array}{l}\text { Latitude }^{4} \\
\text { (degree) }\end{array}$ & $\begin{array}{c}\text { Longitude }^{4} \\
\text { (degree) }\end{array}$ & $\begin{array}{l}\text { Elevation } \\
\quad(\mathbf{f t})\end{array}$ & $\begin{array}{c}\text { Age }^{5} \\
(\mathrm{yr} \\
\text { B.P. })\end{array}$ & $\begin{array}{l}\text { S.D. } \\
(y r)\end{array}$ & $\begin{array}{l}\text { Weighted } \\
\text { average }^{6} \\
\text { (yr B.P.) }\end{array}$ & $\begin{array}{l}\text { S.D. } \\
(y r)\end{array}$ & Quality $^{7}$ & $\begin{array}{c}\text { Age range }^{8} \\
\text { (calendar } \\
\text { years) }\end{array}$ & Source $^{9}$ \\
\hline 19.70961 & -155.27281 & 3,625 & 3,110 & 60 & 3,404 & 25 & 0 & -1505 to -1213 & 2 \\
\hline 19.70522 & -155.11671 & 555 & 3,140 & 70 & 3,404 & 25 & 0 & -1606 to -1215 & 2,5 \\
\hline 19.69773 & -155.12492 & 710 & 3,360 & 80 & 3,404 & 25 & + & -1879 to -1462 & $2,4,5$ \\
\hline 19.71529 & -155.13588 & 840 & 3,380 & 80 & 3,404 & 25 & + & -1885 to -1499 & $2,4,5$ \\
\hline 19.71558 & -155.15315 & 980 & 3,450 & 60 & 3,404 & 25 & + & -1920 to -1618 & 2 \\
\hline 19.71383 & -155.09883 & 220 & 3,450 & 200 & 3,404 & 25 & + & -2341 to -1301 & 4 \\
\hline 19.71610 & -155.15150 & 1,080 & 3,660 & 60 & 3,404 & 25 & 0 & -2201 to -1889 & 3 \\
\hline 19.71801 & -155.13851 & 863 & 3,700 & 70 & 3,404 & 25 & 0 & -2290 to -1899 & 2 \\
\hline 19.71550 & -155.31470 & 4,310 & 3,790 & 200 & 3,433 & 44 & 0 & -2864 to -1694 & 2 \\
\hline 19.71550 & -155.31470 & 4,310 & 3,415 & 45 & 3,433 & 44 & + & -1879 to -1615 & 3 \\
\hline 19.34300 & -155.52620 & 6800 & 4020 & 60 & 4135 & 49 & + & -2856 to -2352 & 3 \\
\hline 19.36450 & -155.38770 & 3020 & 4340 & 80 & 4135 & 49 & + & -3328 to -2710 & 3 \\
\hline 19.59460 & -155.34485 & 5,780 & 4,070 & 70 & 4,173 & 21 & + & -2872 to -2471 & 2 \\
\hline 19.68495 & -155.14573 & 1,160 & 4,170 & 90 & 4,173 & 21 & + & -2919 to -2489 & 2 \\
\hline 19.69175 & -155.15203 & 1,220 & 4,210 & 80 & 4,173 & 21 & + & -3011 to -2505 & 2 \\
\hline 19.69175 & -155.15203 & 1,220 & 4,128 & 26 & 4,173 & 21 & + & -2869 to -2582 & 3 \\
\hline 19.72380 & -155.08780 & 70 & 4,410 & 60 & 4,173 & 21 & + & -3334 to -2906 & 3 \\
\hline 19.69048 & -155.12012 & 600 & 4,410 & 120 & 4,173 & 21 & 0 & -3497 to -2701 & $2,4,5$ \\
\hline 19.71870 & -155.27474 & 3,630 & 4,690 & 60 & 4,695 & 58 & + & -3638 to -3354 & 2 \\
\hline 19.71554 & -155.30811 & 4,240 & 4,790 & 250 & 4,695 & 58 & + & -4217 to -2897 & 2 \\
\hline 19.61100 & -155.03200 & 320 & 5,250 & 100 & 5,455 & 25 & + & -4330 to -3806 & 2,5 \\
\hline 19.61100 & -155.03200 & 320 & 5,480 & 30 & 5,455 & 25 & + & -4435 to -4260 & 3 \\
\hline 19.56506 & -155.12863 & 1,660 & 5,520 & 170 & 5,455 & 25 & + & -4718 to -3979 & 3 \\
\hline 19.61680 & -155.03930 & 359 & 5,425 & 55 & 5,455 & 25 & + & -4363 to -4060 & 3 \\
\hline 19.55023 & -155.10518 & 1,420 & 5,360 & 110 & 5,534 & 70 & + & -4447 to -3961 & 3 \\
\hline 19.54285 & -155.12443 & 1,730 & 5,650 & 90 & 5,534 & 70 & + & -4710 to -4335 & 1,2 \\
\hline 19.51236 & -155.32634 & 5,440 & 7,960 & 110 & & & + & -7174 to -6593 & 2 \\
\hline 19.65428 & -155.13903 & 1,220 & 8,030 & 70 & & & + & -7142 to -6692 & 2,5 \\
\hline 19.41967 & -155.33883 & 3,680 & 8,550 & 100 & 8,645 & 71 & + & -7865 to -7379 & 1,2 \\
\hline 19.43567 & -155.32917 & 4,000 & 8,740 & 100 & 8,645 & 71 & + & -8207 to -7581 & 2 \\
\hline 19.71430 & -155.08330 & 45 & 8,365 & 140 & 8,673 & 55 & + & -7631 to -7053 & 3 \\
\hline 19.72110 & -155.08960 & 60 & 8,730 & 60 & 8,673 & 55 & + & -8160 to -7595 & 3 \\
\hline 19.66064 & -155.12770 & 900 & 9,020 & 130 & 9,020 & 88 & + & -8549 to -7756 & $2,4,5$ \\
\hline 19.68732 & -155.07227 & 170 & 9,020 & 120 & 9,020 & 88 & + & -8543 to -7790 & 5 \\
\hline 19.65059 & -155.14646 & 1,440 & 9,480 & 60 & 9,672 & 40 & + & -9130 to -8623 & 3 \\
\hline 19.65395 & -155.13933 & 1,242 & 9,540 & 110 & 9,672 & 40 & 0 & -9236 to -8626 & 2 \\
\hline 19.65891 & -155.10083 & 660 & 9,780 & 140 & 9,672 & 40 & + & -9753 to -8767 & $2,4,5$ \\
\hline 19.65549 & -155.13789 & 1,180 & 9,960 & 70 & 9,672 & 40 & + & -9761 to -9285 & 2 \\
\hline 19.71833 & -155.27300 & 3,600 & 10,090 & 120 & 10,161 & 29 & + & -10124 to -9304 & 2 \\
\hline 19.71833 & -155.27300 & 3,600 & 10,165 & 30 & 10,161 & 29 & + & -10073 to -9763 & 3 \\
\hline 19.51457 & -155.31963 & 5,365 & 10,400 & 150 & & & + & -10838 to -9808 & 2 \\
\hline 19.72166 & -155.26759 & 3,600 & 10,140 & 60 & 10,405 & 37 & + & -10096 to -9458 & 3 \\
\hline 19.70652 & -155.20067 & 2,175 & 10,150 & 80 & 10,405 & 37 & + & -10128 to -9451 & 2 \\
\hline 19.71622 & -155.15037 & 1,065 & 10,480 & 145 & 10,405 & 37 & + & -10868 to -9894 & 3 \\
\hline 19.72330 & -155.11624 & 460 & 10,610 & 150 & 10,405 & 37 & 0 & -10913 to -10161 & $2,4,5$ \\
\hline 19.72210 & -155.11290 & 400 & 10,900 & 70 & 10,405 & 37 & 0 & -11018 to -10851 & 3 \\
\hline 19.51606 & -155.12799 & 1,875 & 10,660 & 400 & & & + & -11308 to -9329 & 2 \\
\hline 19.71990 & -155.10853 & 325 & 13,530 & 180 & 14,173 & 37 & + & -14733 to -13544 & $2,4,5$ \\
\hline 19.72034 & -155.12002 & 530 & 14,080 & 150 & 14,173 & 37 & + & -15421 to -14305 & $2,4,5$ \\
\hline 19.71164 & -155.16796 & 1,480 & 14,080 & 160 & 14,173 & 37 & + & -15452 to -14289 & 2 \\
\hline
\end{tabular}


Table 2. Radiocarbon ages of samples from the northeast flank of Mauna Loa, Island of Hawai'i, Hawaii.—Continued

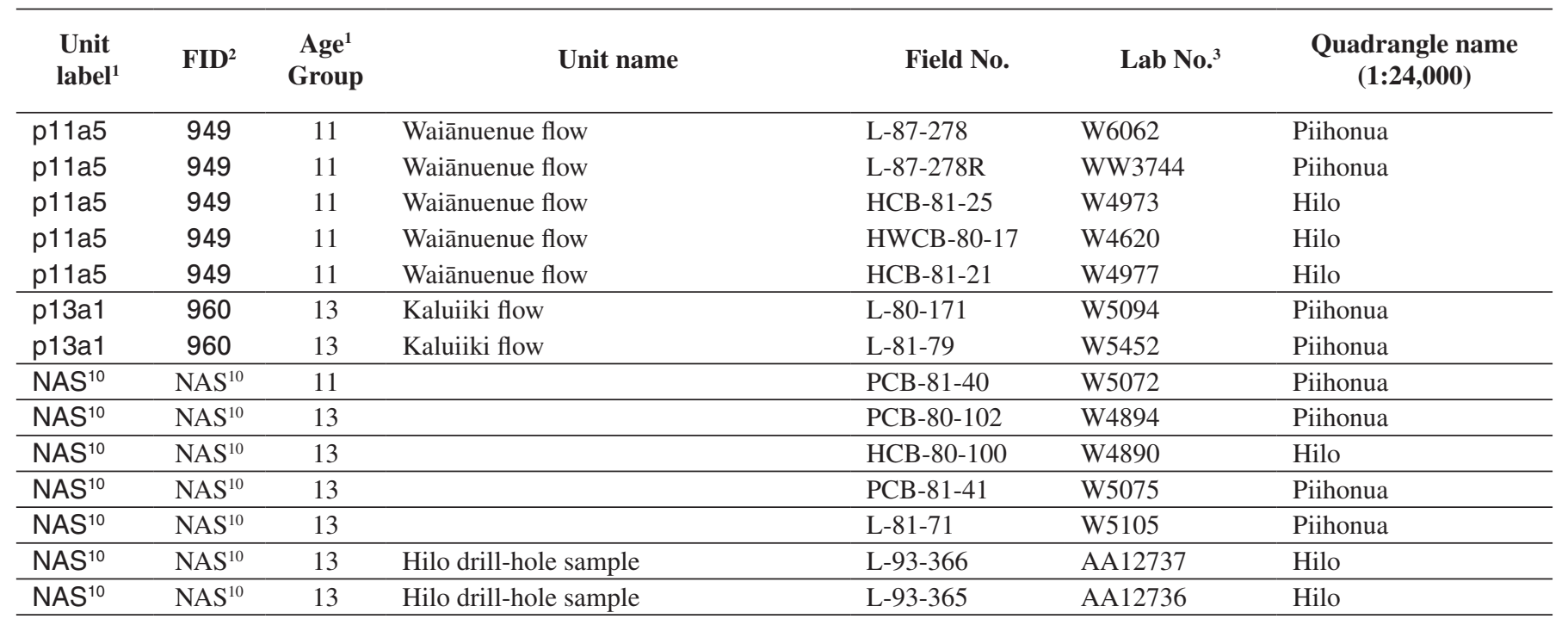

${ }^{1}$ See table 3 for explanation of unit labels and definition of age groups.

${ }^{2}$ Unique, three-digit flow identification number (FID) assigned to each mapped surface-flow unit correlates with database (https://doi.org/10.3133/sim2932A).

${ }^{3}$ Initial letter(s) identifies analytical laboratory: A, University of Arizona, Tucson, Ariz; SUERC, NERC radiocarbon laboratory, Kilbride, Scotland, UK; USGS, U.S. Geological Survey ${ }^{14} \mathrm{C}$ laboratory, Menlo Park, Calif.; W, U.S. Geological Survey ${ }^{14} \mathrm{C}$ laboratory, Reston, Va..

${ }^{4}$ Transverse Mercator projection; Old Hawaiian Datum. See base Information below left corner of map.

${ }^{5}$ Calibrated ages are for two standard deviations.

${ }^{6}$ Weighted average, each age is weighted by the inverse of its variance before averaging (for example, Taylor 1982). A variance is reported as one standard deviation, in years.

${ }^{7}$ Quality: +, age considered meaningful; 0, age probably meaningful but accuracy may be poorer than indicated by the reported precision.

${ }^{8}$ Each age was calibrated to calendar years using CALIB 4.0 Radiocarbon Calibration Program (Stuiver and others, 1998); calibrated ages are for two standard deviations. Entire age range of calendar ages are possible for a given sample. Unspecified ages, A.D.; negative (-) ages, B.C.

9Sources: 1, Kelley and others, 1979; 2, Rubin and others, 1987; 3, this study; 4, Buchanan-Banks and others, 1989; 5, Buchanan-Banks, 1993.

${ }^{10} \mathrm{NAS}$, flows not found at surface are exposed in drainages, fault scarps, and (or) sea cliffs.

${ }^{11}$ Samples collected outside of map area.

${ }^{12} \mathrm{NAC}$, not able to calibrate ${ }^{14} \mathrm{C}$ age because too old for CALIB program. 


\begin{tabular}{|c|c|c|c|c|c|c|c|c|c|}
\hline $\begin{array}{l}\text { Latitude }^{4} \\
\text { (degree) }\end{array}$ & $\begin{array}{c}\text { Longitude }^{4} \\
\text { (degree) }\end{array}$ & $\begin{array}{l}\text { Elevation } \\
\quad(\mathbf{f t})\end{array}$ & $\begin{array}{c}\text { Age }^{5} \\
(\mathrm{yr} \\
\text { B.P. })\end{array}$ & $\begin{array}{l}\text { S.D. } \\
(y r)\end{array}$ & $\begin{array}{l}\text { Weighted } \\
\text { average }^{6} \\
\text { (yr B.P.) }\end{array}$ & $\begin{array}{l}\text { S.D. } \\
(y r)\end{array}$ & Quality $^{7}$ & $\begin{array}{c}\text { Age range }^{8} \\
\text { (calendar } \\
\text { years) }\end{array}$ & Source $^{9}$ \\
\hline 19.71200 & -155.22050 & 2,560 & 14,240 & 400 & 14,173 & 37 & + & -16537 to -14063 & $2,4,5$ \\
\hline 19.71200 & -155.22050 & 2,560 & 14,150 & 45 & 14,173 & 37 & + & -15302 to -14513 & 3 \\
\hline 19.71582 & -155.12325 & 610 & 14,370 & 190 & 14,173 & 37 & + & -16002 to -14653 & $2,4,5$ \\
\hline 19.72221 & -155.12426 & 535 & 14,500 & 200 & 14,173 & 37 & + & -16478 to -14707 & $2,4,5$ \\
\hline 19.71808 & -155.11627 & 480 & 14,530 & 120 & 14,173 & 37 & + & -16032 to -15015 & $2,4,5$ \\
\hline 19.69817 & -155.13360 & 840 & 28,120 & 400 & 28,145 & 333 & + & NAC $^{12}$ & 2 \\
\hline 19.69725 & -155.13719 & 940 & 28,200 & 600 & 28,145 & 333 & + & $\mathrm{NAC}^{12}$ & 2 \\
\hline 19.65794 & -155.13173 & 1,000 & 10,320 & 70 & & & + & -10617 to -9876 & $2,4,5$ \\
\hline 19.65888 & -155.13083 & 1,000 & 21,900 & 270 & & & + & NAC $^{12}$ & $2,4,5$ \\
\hline 19.69743 & -155.12411 & 680 & 23,840 & 600 & & & + & $\mathrm{NAC}^{12}$ & $2,4,5$ \\
\hline 19.66132 & -155.12742 & 880 & 24,240 & 500 & & & + & $\mathrm{NAC}^{12}$ & $2,4,5$ \\
\hline 19.41648 & -155.34947 & 2,180 & $>38,000$ & & & & 0 & $\mathrm{NAC}^{12}$ & 2 \\
\hline 19.73433 & -155.05200 & -599.92 & 37,430 & 1,050 & 38,598 & 907 & + & $\mathrm{NAC}^{12}$ & 3 \\
\hline 19.73433 & -155.05200 & -595.6 & 42,030 & 1,800 & 38,598 & 907 & + & $\mathrm{NAC}^{12}$ & 3 \\
\hline
\end{tabular}

